\title{
CANALES, SIFONES Y ALMENARAS. EL IMPACTO AMBIENTAL DE LAS INFRAESTRUCTURAS DEL CANAL DE ISABEL II (MADRID) ${ }^{1}$
}

\author{
José A. Sotelo Navalpotro² y María Sotelo Pérez ${ }^{3}$ \\ Instituto Universitario de Ciencias Ambientales \\ Universidad Complutense de Madrid
}

\section{RESUMEN}

El presente artículo tiene como finalidad, valorar el impacto ambiental de las conducciones del Canal de Isabel II en el contexto del paisaje. Partimos de la idea según la cual, las infraestructuras del Canal de Isabel II, y más que formar parte del paisaje por el que se extienden, son el propio paisaje. Nuestra zona de estudio es el noroeste de la Comunidad de Madrid (síntesis de la interacción de los propios agentes naturales, de la ocupación humana y de los usos del suelo), área a la que nos aproximarnos a través de la investigación de la integración paisajística, entendida ésta como una estrategia de intervención en el territorio, que tiene como objetivo principal orientar las transformaciones del paisaje o corregir las ya realizadas, para conseguir su adaptación al propio paisaje. En definitiva, nos encontramos ante la necesidad de ajustar un objeto o actuación territorial a las características fisonómicas de un paisaje dado, o de algunos de sus componentes, así como a su carácter y a sus contenidos semánticos.

Palabras clave: Canal de Isabel II, paisaje, impacto ambiental, integración ambiental, infraestructuras, agua.

\begin{abstract}
Channels, siphons and beacons. Environmental impact of Canal Isabel II infrastructure (Madrid)

This research seeks to assess the environmental impact of the Canal de Isabel II channels in the context of the landscape. We start from the idea that, infrastructure Canal Isabel II, and more than part of the landscape through which they extend, are the landscape itself. Our study area is the northwest of the Community of Madrid (synthesis of the interaction of the agents themselves natural, human occupation and land use), an area to which we approach through research landscape integration, understood as an intervention strategy in the territory, which aims to guide the main changes in the landscape or correct already made, to get your own landscape adaptation. In short, we are faced with the need to adjust an object or action territorial physiognomic characteristics of a given landscape, or some of its components, as well as their character and semantic content.

Key words: Canal de Isabel II, landscape, environmental impact, environmental integration, enfrastructure, water.

\footnotetext{
El presente artículo se inserta en el proyecto de investigación/art. 83 (UCM y CYII), en el año 2012, titulado: "Los primeros canales del Lozoya: patrimonio hidráulico del Canal de Isabel II".

2 Grupo de Investigación UCM: Desarrollo y Gestión Ambiental del Territorio. Contacto: jasotelo@ucm.es

3 Grupo de Investigación UCM: Desarrollo y Gestión Ambiental del Territorio. Becaria FPU. Contacto: maria_sotelo_perez@hotmail.com
} 


\section{INTRODUCCIÓN: INFRAESTRUCTURAS QUE CREAN PAISAJE E INFLUYEN EN EL PAISANAJE}

El agua es un recurso limitado, aunque creamos lo contrario, puesto que no todo el mundo tiene acceso a este bien tan preciado y tan necesario para la supervivencia humana. La disponibilidad de consumo o abastecimiento de agua, ha sido el centro principal de los asentamientos de las poblaciones, en unos u otros emplazamientos, como punto de referencia para la supervivencia de sus gentes y como núcleo de partida del desarrollo de las distintas actividades económicas. El problema principal de este bien es la escasez puesto que, en la mayoría de los casos, las demandas de agua exceden sustancialmente a la propia oferta natural del agua. Nuestro país atraviesa por un período de escasez de lluvias preocupante -tamizado por las últimas precipitaciones primaverales-, algo a lo que no son ajenos los municipios madrileños y los alcarreños. A este fenómeno coyuntural se añade la insostenible gestión del agua de nuestros ríos que, desde hace años, se lleva a cabo desde las diferentes administraciones que tienen encomendada su conservación (en el caso de Madrid el Canal de Isabel II y Confederación Hidrográfica del Tajo). El resultado de esta combinación explica las actuales amenazas al abastecimiento y el escaso o nulo caudal que circula por los cauces de nuestros ríos.

En Madrid, el agua procede de la regulación artificial de las cuencas hidrográficas de la sierra Madrileña, e incluso de lugares más alejados, y de las captaciones de aguas subterráneas que se realizan en la cuenca terciaria. Este agua es conducida por una extensa red de tuberías a las estaciones de tratamiento de aguas potables, de aquí a los depósitos de regulación y de estos a los usuarios. Una vez utilizada el agua, ésta se envía a través de la red de saneamiento a las estaciones regeneradoras de aguas residuales y de aquí se vierte nuevamente a los cauces del Manzanares y Jarama.

En este ámbito, el abastecimiento incluye los servicios de aducción y de distribución. En general, suele ser asumido por los Ayuntamientos, pero por razones históricas, en el caso de Madrid, se encomienda la gestión integral al Canal de Isabel II (CYII), ente dependiente de la Comunidad Autónoma madrileña. Y es que Madrid dispone de una red de infraestructuras y de distribución bien desarrollada que además de ofrecer un buen servicio, eleva las garantías de suministro y el control de la demanda. Todo ello sin olvidarnos que en la actualidad el capital físico hidráulico del Canal de Isabel II incluye 14 embalses, 550 kilómetros de grandes conducciones, 19 estaciones elevadoras, 12 plantas de potabilización, 22 grandes depósitos de regulación y 274 de tamaño menor; a esto hay que añadir 15.000 kilómetros de red de distribución y 6.600 de alcantarillado amén de 150 estaciones de depuración, 66 de aprovechamiento de agua subterránea y 6 instalaciones de agua reutilizable.

Así pues, las infraestructuras del Canal de Isabel II pueden valorarse en su impacto ambiental desde una perspectiva visual, en general, cultural y estética, en particular. Teniendo en cuenta que han pasado casi ciento sesenta años desde el inicio de su construcción, en la actualidad más que formar parte del paisaje, son ellas el propio paisaje. Si nos aproximamos al vocablo "infraestructuras", éste nos acerca a un conjunto de hechos con características formales, dinámicas evolutivas e incidencia paisajística muy diferentes. Para la comprensión del territorio como sistema de relaciones y para el entendimiento del paisaje como marco de vida, como matriz de coherencia ecológica, funcional y cultural, conviene mantener una mirada conjunta sobre el concepto amplio de infraestructuras; pero para la protección, gestión y ordenación de los distintos elementos presentes en el territorio o en el paisaje, muchos de ellos infraestructurales, es también necesario establecer de manera particularizada sus peculiaridades y repercusiones.

El paisaje queda sujeto a la doble indeterminación que su apariencia cambiante le añade, y a la capacidad e interés del que lo contempla. El paisaje pasa a ser el resultado de la interacción existente entre el observador y el entorno, poniendo de manifiesto la existencia de imágenes individuales, de imágenes colectivas (propias de grupos humanos que concuerdan en su apreciación) y de paisajes en abstracto (que han cobrado universal significado). No son pocos los que opinan que tras la contemplación viene la acción, comprendiéndose mejor el que en no pocas ocasiones las intervenciones realizadas sobre la naturaleza son, cuando menos, apresuradas, demoledoras, en lucha abierta con ella, degradante. 
A esta acción del hombre sobre el paisaje corresponde otra en sentido opuesto, acaso menos patente pero igualmente real. Pese a que los artistas plásticos y los escritores lo hayan descubierto en un determinado momento y lo interpreten de manera diferente en cada nuevo periodo histórico o cultural (el paisaje puede valorarse, igualmente, como el territorio en clave histórica), el paisaje no es la simple escenografía que nos rodea, sino el molde físico al que tras la suma del molde humano llega a conformar el cuadro geográfico que de alguna manera determina las costumbres de una zona, comarca o región, formando el carácter y explicando las cualidades y los gustos de las gentes (paisanaje) que lo vive. De aquí que se relacione íntimamente con la forma de ser de quien lo habita y lo puebla, ayudándole a su comprensión y a su más exacto conocimiento, aspectos éstos de gran interés a la hora de valorar el impacto ambiental de estas infraestructuras.

\subsection{Localización geográfica y entorno regional de la zona de estudio}

El territorio estudiado se circunscribe a la Comunidad de Madrid, y al espacio que limita con la zona nororiental de la Comunidad de Castilla-La Mancha, en la provincia de Guadalajara, circunscrito al curso de una de sus principales arterias fluviales: el río Jarama y sus afluentes (especialmente, el Lozoya). Abarca, por tanto, los dos grandes dominios geológicos regionales constituyentes de este territorio, el Sistema Central y la cuenca mesocenozoica del Tajo o de Madrid. Nuestro objetivo fundamental es estudiar las conducciones de agua (sifones) que permiten abastecer a Madrid (Canales del Villar, de la Parra, del Lozoya, Alto y Bajo). En la figura 1 podemos observar que la zona por la que se extienden las conducciones que estamos estudiando, se encuadra entre los 40 $58^{\prime} 58^{\prime \prime}$ y los $40^{\circ} 28^{\prime} 54^{\prime \prime}$ latitud norte, y, $\operatorname{los} 3^{\circ} 39^{\prime} 03^{\prime \prime}$ y los $3^{\circ} 21^{\prime} 51^{\prime \prime}$ de longitud oeste.

Figura 1. Localización de la zona de estudio.

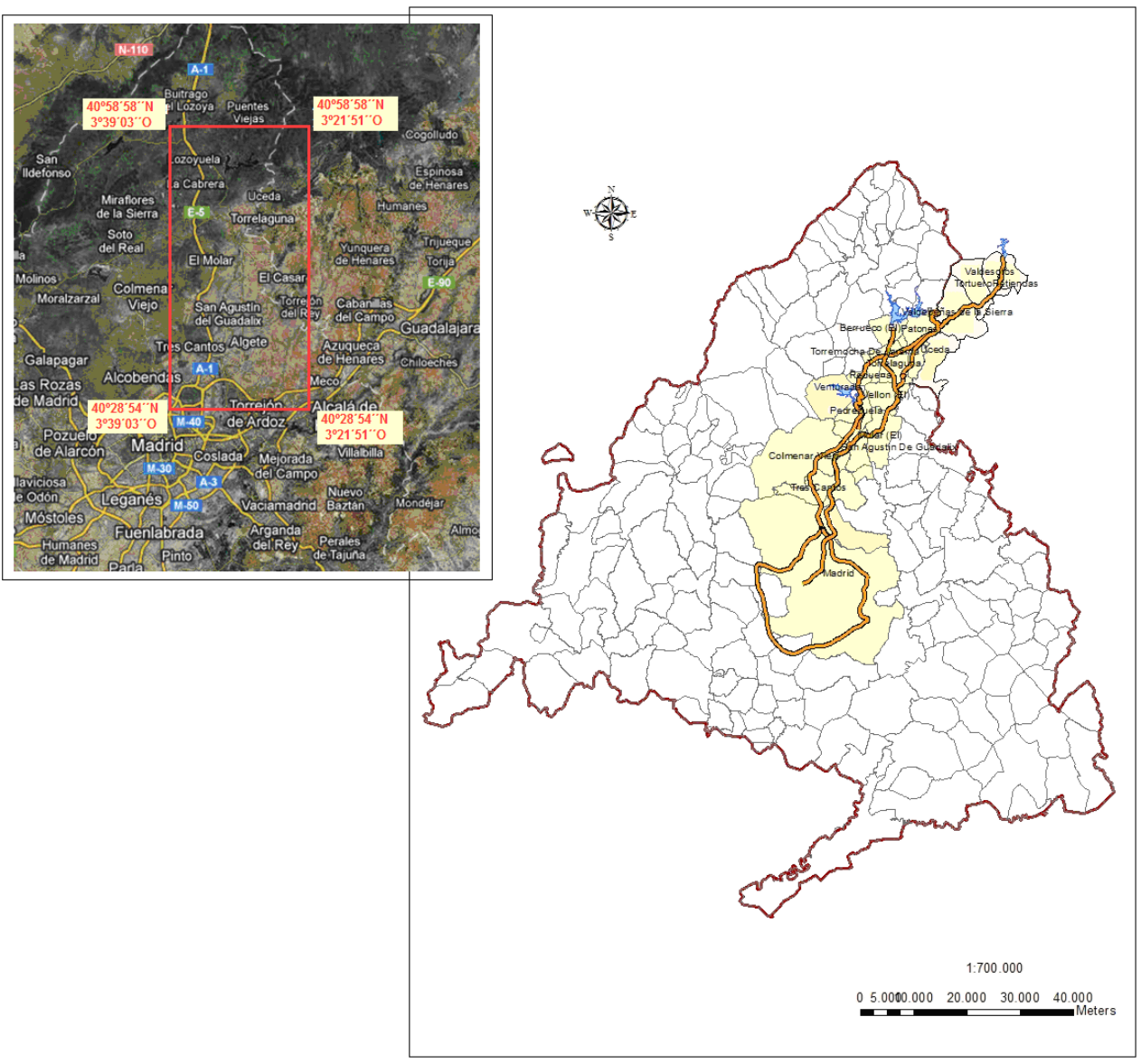

Elaboración propia 
El entorno geográfico de los canales descritos está marcado por la realidad hoy conocida como Comunidad de Madrid. Nos encontramos ante un marco territorial de reducidas dimensiones, pues posee una superficie de $8.030 \mathrm{~km}^{2}$; se trata de una pequeña parte del interior de la Meseta, unidad del relieve peninsular en la que se enmarca. Este conjunto presenta un contorno triangular definido por los límites provinciales en 1833, con un vértice norte en el Puerto de Somosierra, Aranjuez al sur, el municipio de Estremera en el Sureste, -a orillas del río Tajo-, y el municipio de Cenicientos en el Suroeste, al pie de las alineaciones más orientales de Gredos.

Las infraestructuras existentes para la aducción de agua en la Comunidad de Madrid son: catorce embalses con una capacidad total de $946 \mathrm{hm}^{3}, 122$ captaciones de aguas subterráneas con una extracción máxima admisible de $85 \mathrm{hm}^{3}$, doce estaciones de tratamiento de agua potable con una capacidad conjunta de $43 \mathrm{~m}^{3} / \mathrm{s}$, veintidós depósitos con una capacidad de regulación de $2,67 \mathrm{hm}^{3}$, dieciocho estaciones de impulsión con una potencia instalada de $78.000 \mathrm{~kW}$.

Figura 2. Marco territorial del área de estudio.
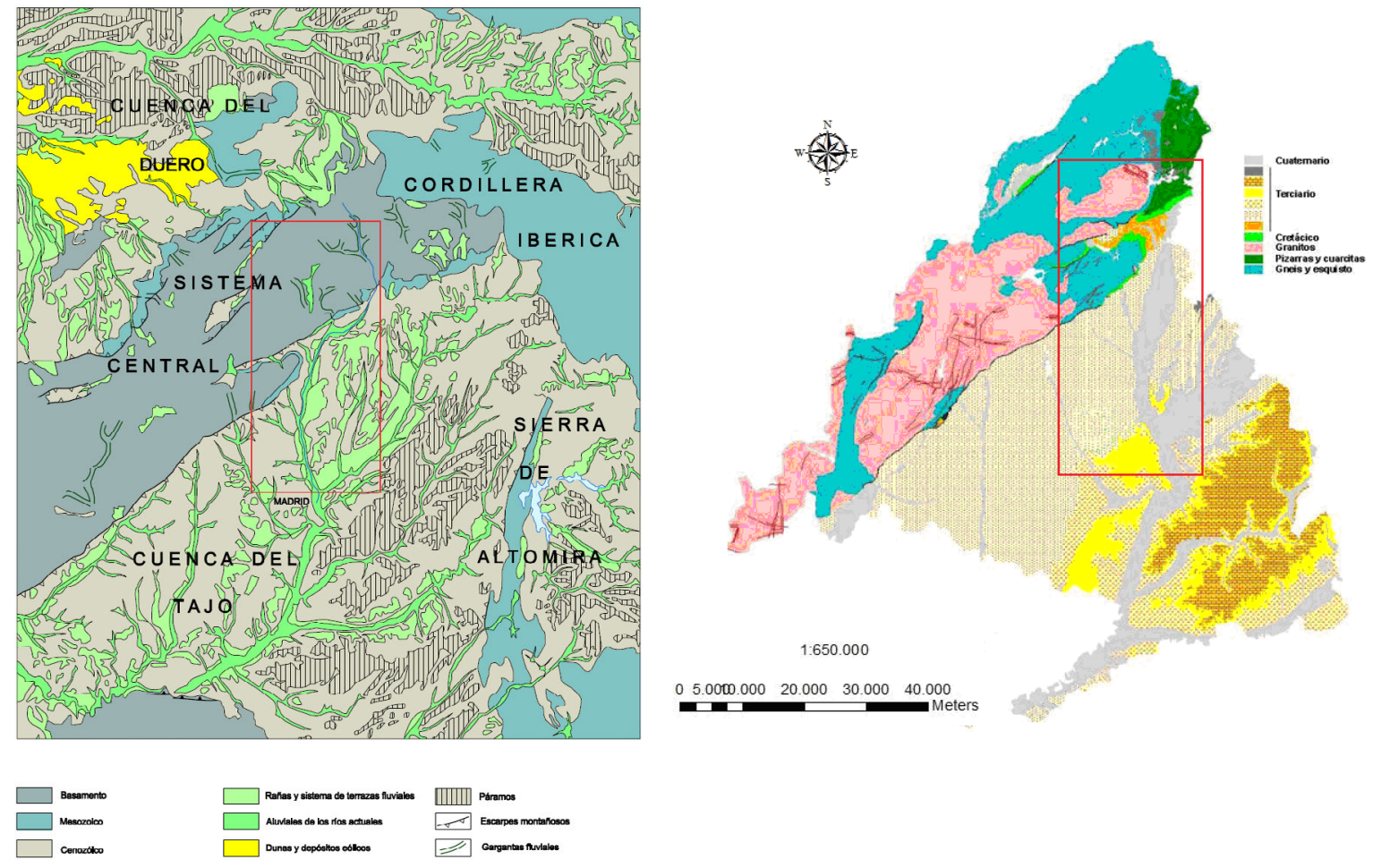

Fuente: Vázquez, I. (2009). Elaboración propia.

\section{MATICES EN EL IMPACTO DE LAS INFRAESTRUCTURAS. LA INTEGRACIÓN DE LAS CONDUCCIONES DE AGUA DEL CANAL, EN EL PAISAJE}

La integración de las conducciones del Canal en el paisaje parte de una primera idea a destacar, la apreciación estética que hoy está marcada por el esfuerzo realizado por lograr una alta calidad sensorial de los recursos, destacando el esfuerzo que se realizó desde las primeras construcciones, en alcanzar un alto nivel de agrado, por parte del observador. De hecho, al paisaje de nuestra zona de estudio hay que sumar la morfología del terreno, su cubierta, las propias infraestructuras convirtiéndolo en un verdadero recurso estético (síntesis de los principales rasgos naturales y culturales del medio ambiente, que consiguen promover diferentes reacciones sensoriales de aprecio en los observadores que lo disfrutan).

Es en este contexto en el que la inserción de las infraestructuras rurales dispersas o concentradas en el paisaje constituye un desafío para la gestión del paisaje, en general, y para la política territorial en 
particular. La integración paisajística de las intervenciones humanas y de las construcciones constituye una demanda social y, de forma reciente, administrativa, que, sin embargo, adolece de planteamientos teóricos sólidos, así como de desarrollos metodológicos específicos. En los últimos tiempos, el problema de la integración en el paisaje de las actividades humanas, y en concreto de las infraestructuras del Canal de Isabel II, ha experimentado un interés creciente en la sociedad española, en general, y de Madrid, en particular, en consonancia con lo vivido en las sociedades más avanzadas. En cierta medida, la integración paisajística ha supuesto la incorporación de una nueva variante temática al interés social por el paisaje, trascendiendo y sumándose a la ya más consolidada preocupación por la conservación de los paisajes más valiosos. Aporta también una dimensión territorial más amplia, porque afecta o puede afectar al conjunto del territorio, al mismo tiempo que introduce una escala de análisis más cercana, abordando problemas concretos, y una evidente utilidad aplicada, ya que trata de prevenir o corregir impactos sobre el paisaje. En su estudio, nos encontramos con las fases marcadas por Westmen para la evaluación de impacto ambiental (ver figura 3).

La valoración del impacto ambiental de las conducciones de agua a Madrid, tanto en los "pre" como en los "post" impactos están marcados por su carácter "histórico", de tal forma que la integración paisajística surge como resultado de la inquietud social generada por el avance de la construcción hoy detenido- en el conjunto del territorio y por ende de la demanda de agua, fenómeno especialmente preocupante en los espacios rurales de Madrid y Guadalajara. Ligado a fenómenos de difusión urbana de diversa índole, como los procesos de "periurbanización" y "rururbanización", o a la expansión del turismo residencial, el desarrollo de la construcción, muy alto en la última década, en determinadas zonas de la Comunidad, ha alcanzado a los espacios rurales, incluso a algunos claramente distantes de los focos irradiadores. De esta manera, valorar el impacto ambiental de las conducciones del Canal de Isabel II en el contexto del paisaje, entendiendo el mismo como la extensión del escenario natural, suma total de las características que distinguen un territorio concreto, en nuestro caso el noroeste de la Comunidad de Madrid (síntesis de la interacción de los propios agentes naturales, de la ocupación humana y de los usos del suelo) supone aproximarnos a la integración paisajística como una estrategia de intervención en el territorio, que tiene como objetivo orientar las transformaciones del paisaje o corregir las ya realizadas para conseguir adecuarlas al paisaje tomado como referencia. Así pues, nos encontramos ante la necesidad de ajustar un objeto o actuación territorial a las características fisonómicas de un paisaje dado, o de algunos de sus componentes, así como a su carácter y a sus contenidos semánticos. De esta forma, mediante la integración, un objeto se inserta en un determinado paisaje de tal forma que tiende a fundirse en él. No existe, por tanto, alteración, al menos sustancial, del paisaje existente. A través de unos determinados mecanismos de integración, el objeto renuncia a su protagonismo experimentando un proceso de acomodación al paisaje que lo diluye en él (esto es lo que sucede con las almenaras, y en menor medida con los sifones). Hay que entender, sin embargo, que esto no implica necesariamente la ocultación física del objeto, ni siquiera su inadvertencia: es suficiente para alcanzar una adecuada integración paisajística que el objeto sea percibido como integrado en el paisaje. Es más, incluso en no pocos casos se permite su resalte, generando contrastes con otros componentes paisajísticos, siempre que la heterogeneidad forme parte de la personalidad del paisaje afectado o que las cualidades formales o semánticas en las que se basa el contraste escogido esté presente en otros componentes del paisaje, en nuestro caso las susodichas conducciones del Canal de Isabel II.

Nos encontramos pues con que de la misma forma que ocurre con otras temáticas paisajísticas (como el impacto paisajístico o el análisis de hitos), el factor tiempo posee una importancia crucial para el concepto de integración paisajística, de las conducciones del Canal. Su discurrir permite la integración en el paisaje de la práctica totalidad de las actuaciones humanas, desde construcciones a infraestructuras, desde roturaciones de bosques con fines agrarios a explotaciones mineras, desde núcleos de población a fábricas. La percepción de la integración paisajística se activa en el momento en que se evidencia la antigüedad, la historicidad, de la intervención, considerándose como enraizada, indisolublemente unida con el paisaje donde se encuentra. Lo que hoy emerge como impacto, carente de cualquier posibilidad de integración, puede ser considerado como integrado cuando transcurran, no ya siglos, sino incluso varias décadas. 
Figura 3. Fases de la evaluación de impacto ambiental.

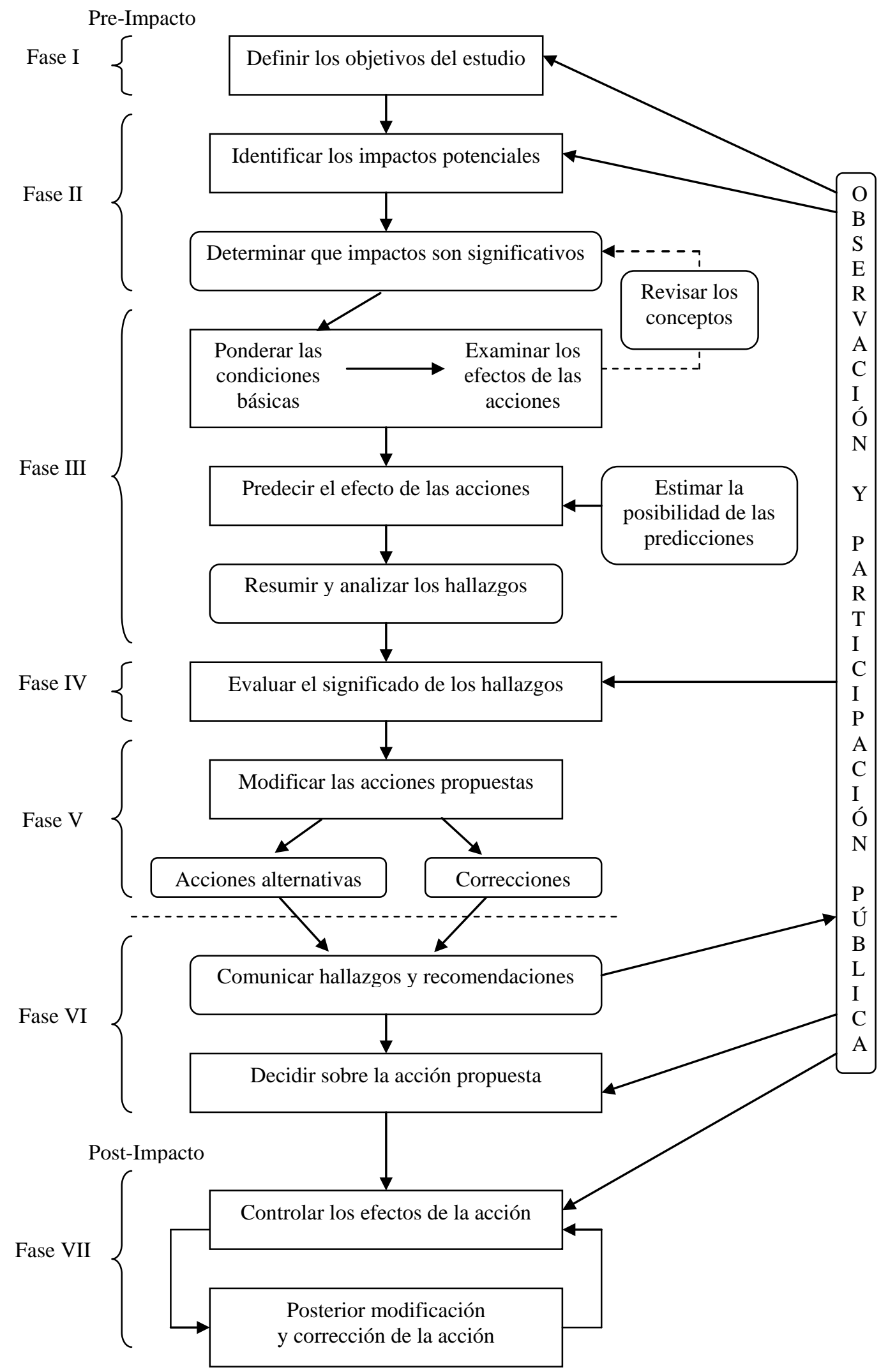

Fuente: Westmen, W.E. (1985). Ecology, Impact Assessment, and Environmental Planning, Jon Wiley and Sons, New York, pp. 10-14. 


\section{LA INTEGRACIÓN PAISAJÍSTICA DE LOS CANALES DEL CANAL}

Tras lo anteriormente expuesto, debemos tener en cuenta que independientemente de la determinación del posible momento de integración efectiva, cuestión en sí de gran trascendencia, y que "mutatis mutandis" debe contemplar al menos el paso de dos o más generaciones, el seguimiento ciego del argumento temporal conllevaría la inacción en materia de integración paisajística, ya que el tiempo terminaría integrando cualquier actuación. Mas, la integración paisajística, como el paisaje, tal y como hemos señalado con anterioridad, es un producto social, y es la sociedad del presente la que demanda disfrutar de paisajes de calidad y utilizarlos como referencia para generaciones futuras (he aquí la importancia de entender el impacto ambiental de las conducciones del Canal, como referencia de la integración paisajística).

No debemos olvidar, la integración del paisaje de una conducción se alcanza, en primera instancia, mediante la elección de un emplazamiento destacado visualmente, que permita dominar la escena, o, en su caso, dotando a la construcción de una altura sensiblemente superior a la existente en su entorno. El segundo paso en la integración del paisaje en la infraestructura, en su absorción, consiste en la sustitución de los paramentos exteriores por materiales pintados, capturando el paisaje e introduciéndolo en la construcción, como parte de su espacio virtual. Estos mecanismos coadyuvan a la integración de las infraestructuras en el espacio. Naturalmente, su valor queda cuando menos transformado si nos encontramos ante el impacto de unas infraestructuras que cuentan con decenas o una centena de años, como en el caso que nos ocupa. Cobra así relativa importancia la fase de "post-impacto", que puede entenderse y valorarse mediante la "integración paisajística" (marcada por la corrección de las acciones anteriores). En nuestra zona de estudio, los canales se distribuyen tal y como puede observarse en las figuras siguientes (ver figuras 4 y 5 ).

Figura 4. Ubicación geológica de los Canales de El Canal.

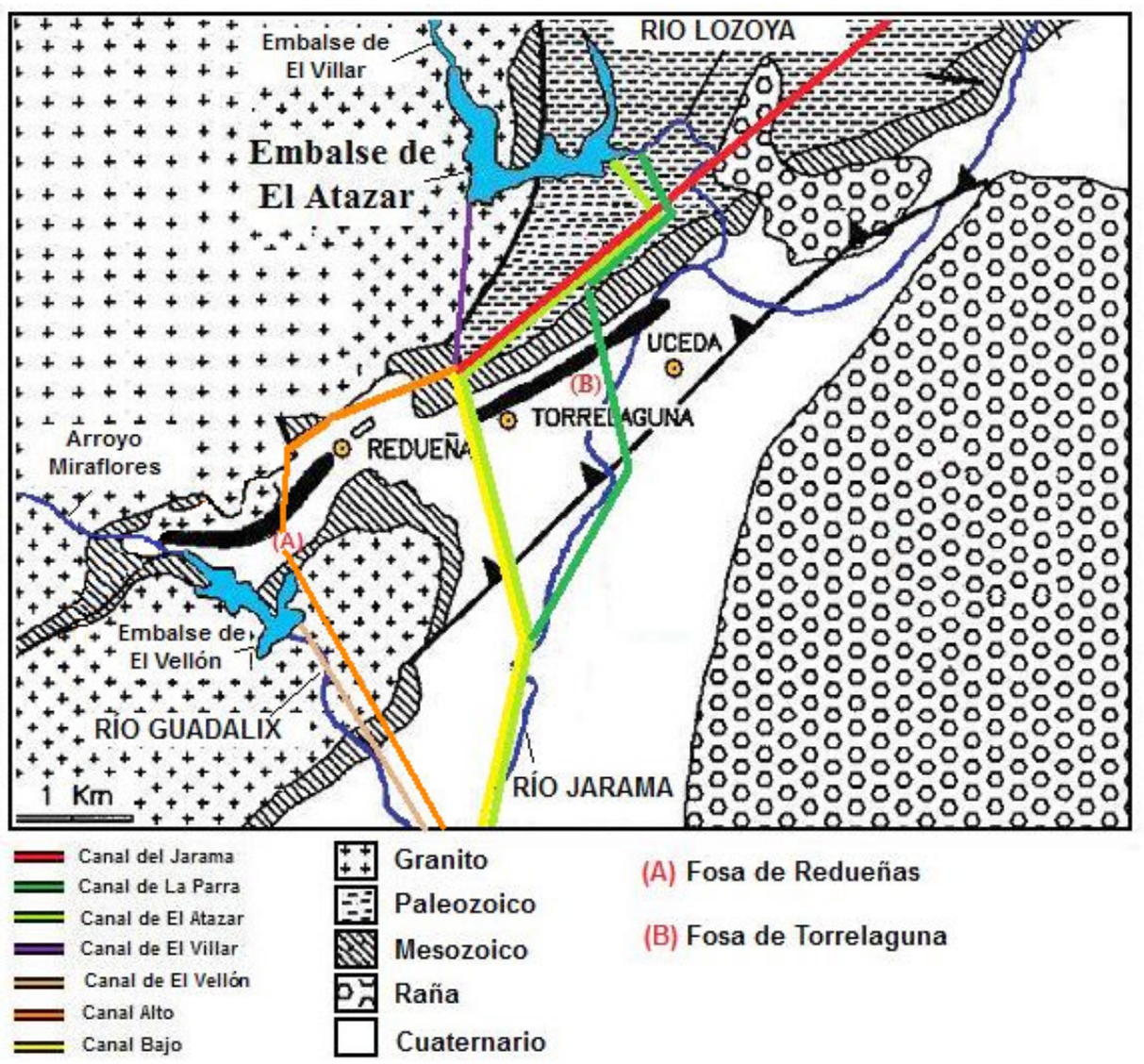

Elaboración propia. 
Figura 5. Localización de canales, sifones y almenaras del CYII.

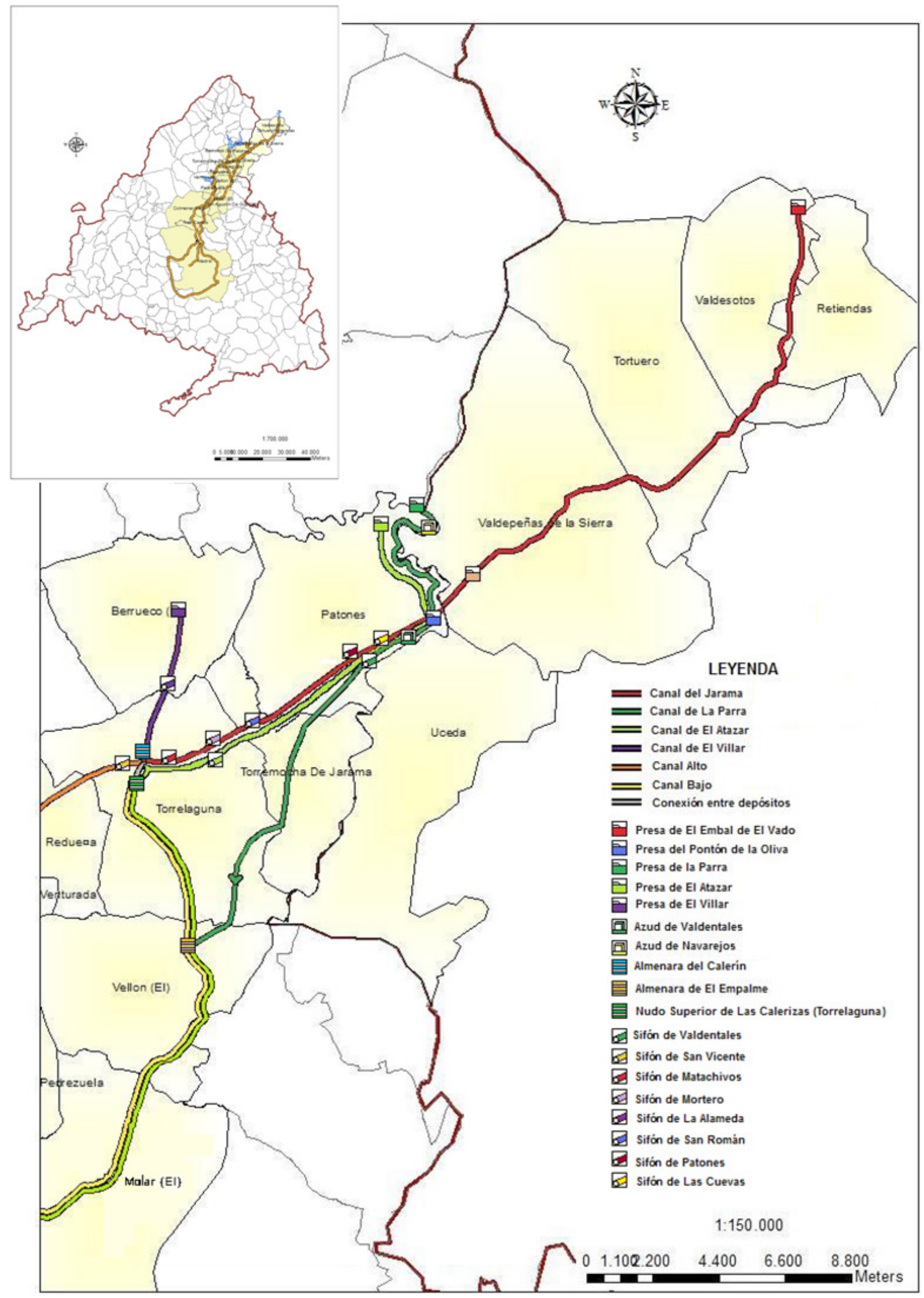

Elaboración propia. 
A lo largo de este tramo del recorrido, siguiendo el curso del Jarama aguas arriba, nos encontramos con el relieve calcáreo a nuestra izquierda, integrado por un relieve estructural en cuesta, que da a lugar un resalte por su mayor competencia erosiva. En la siguiente figura 6, observamos el perfil que muestra la estructura que da origen a la cuesta.

Figura 6. Corte geológico de la zona de estudio.

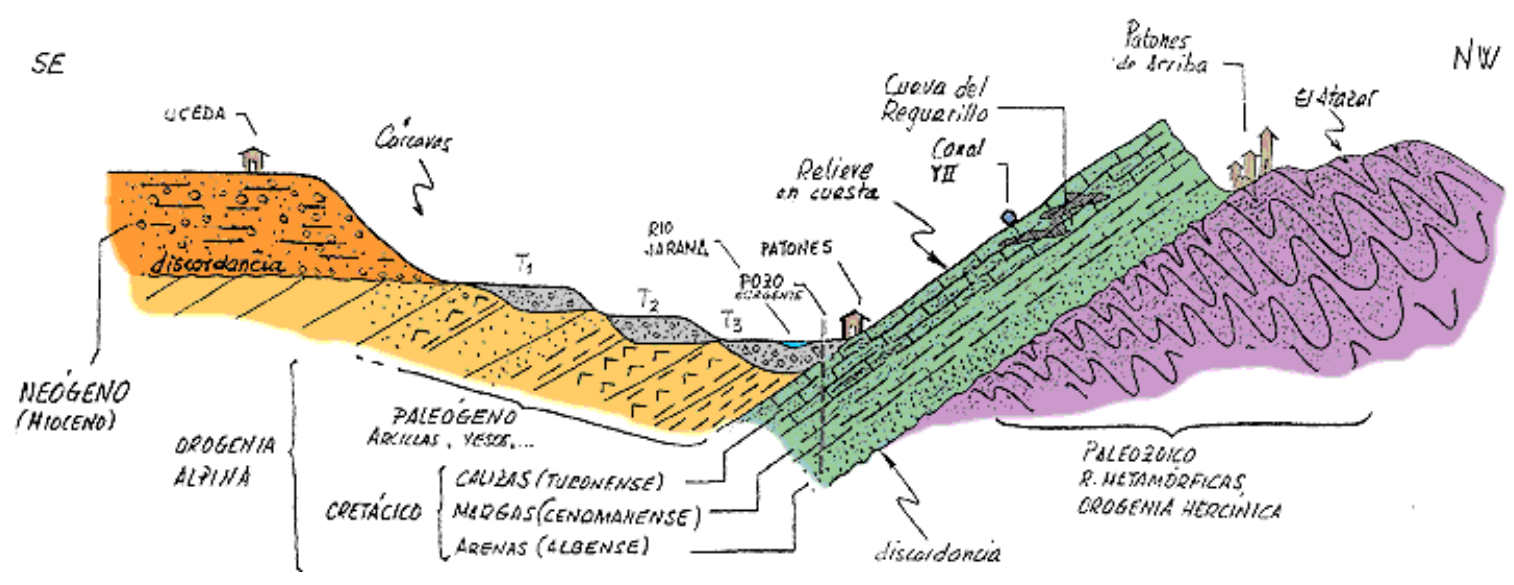

Fuente: http://platea.pntic.mec.es/ cmarti3/2000/campo/jarama/recorr4.htm

Junto a los relieves anteriores, a lo largo del valle en la zona de contacto entre la cuesta calcárea y el aluvial del río, se ubica Patones de Abajo. Es aquí donde observamos el dorso (los estratos buzan hacia el río) de la cuesta, sobre él el trazado de las conducciones del Canal de Isabel II. El más próximo a nosotros es el canal de la Parra, el primero en entrar en servicio en 1858, fecha de la inauguración de la fallida presa del Pontón de la Oliva. A la derecha de la carretera se extiende la llanura aluvial del río Jarama, formada por gravas de cuarcitas de tamaño grueso, de gran importancia hidrogeológica, pues conforman un acuífero en comunicación con el río.

Por otra parte señalar que, en los momentos presentes, el Canal de El Atazar, es el eje principal de abastecimiento de agua a Madrid, relegando a un segundo plano al Canal de El Jarama y al Canal de La Parra. Sin embargo, sus infraestructuras conforman un paisaje perfectamente integrado. Partiremos de éste para mostrar el impacto que sus conducciones generan en el medio ambiente del Noroeste de la Comunidad de Madrid.

El Canal de El Atazar toma sus aguas del Embalse que le da nombre-confluencia de los ríos Lozoya, Jarama y Sorbe- y la transporta hasta el depósito de El Goloso, en las proximidades de Madrid, y el depósito de la Plaza de Castilla. (Ver figura 7)

Tal y como se puede ver en la imagen (ver figura 7), nos encontramos ante un embalse de notables dimensiones, por lo que el impacto ambiental ha sido relativamente elevado. Como es lógico pensar, cualquier construcción de este tipo supone una transformación destacada de los ecosistemas existentes. En la actualidad, no obstante, va a ser el impacto visual -entendido como la importancia o gravedad de la alteración que se produce en la cualidad de los recursos visuales de un paisaje- el más destacable. En el caso del embalse de El Atazar, podemos afirmar que apenas genera un impacto relevante ya que no reduce los valores escénicos del medio sobre el que se asienta. El carácter paisajístico del embalse de El Atazar viene marcado por la variedad e intensidad de rasgos paisajísticos que lo componen, fundamentalmente, los pinares de repoblación, la roca caliza desnuda o teñida de verdes matorrales y las propias infraestructuras y construcciones del Canal de Isabel II.

En un primer tramo, el Canal de El Atazar transporta sus aguas por un túnel de presión (de tres metros de diámetro y casi tres mil cuatrocientos metros de longitud) desde el embalse hasta el azud de Valdentales, concretamente hasta los vestigios de la cámara de rotura de presión que encontramos en el arroyo que da nombre al azud, donde, actualmente, se asienta una central hidroeléctrica de pequeñas dimensiones. 
Figura 7. Vista del embalse de el Atazar.

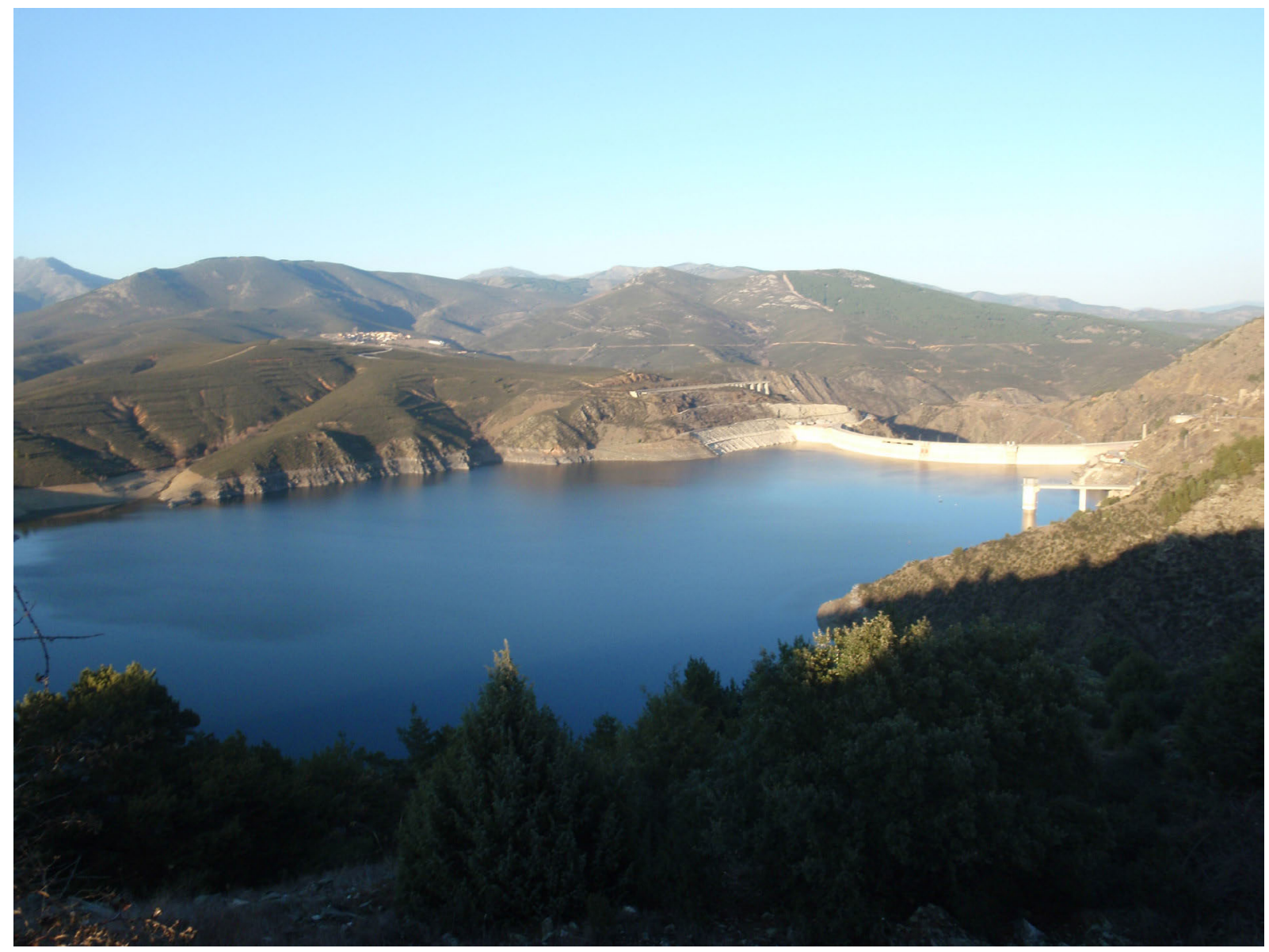

Fuente: José A. Sotelo Navalpotro.

Tras su paso por el azud de Valdentales, el Canal de El Atazar continúa su recorrido, en paralelo a los Canales del Jarama y de la Parra (al pie de la ladera), atravesando los cerros calizos, los barrancos, los páramos y la cuenca aluvial hasta llegar a Torrelaguna. Sobre los cerros serpentean sifones de hormigón armado, conformados por dos tubos de dos metros y veinte centímetros, tintados de colores verdes y "beiges" claritos. Dichos sifones salvan los barrancos desde una almenara de entrada hasta una almenara de salida y, en la parte inferior de los mismos se han construido pontones sobre los que se asientan, soportando así el peso de los sifones (ver figura 8). A pesar de que la mayor parte de los sifones han sido enterrados (sobre todo los del Canal de El Atazar, ya que los del Canal de la Parra permanecen al descubierto en casi todo el recorrido del mismo), aún se puede ver salvando los barrancos de Patones, de Las Cuevas y de San Román, donde el Canal de El Atazar y de El Jarama continúan en paralelo su recorrido, mientras que el Canal de La Parra se desplaza hacia el sur, atravesando el término municipal de Torremocha del Jarama y parte del municipio de Torrelaguna hasta la almenara de El Empalme, en el municipio de El Vellón.

El Canal de El Jarama, el Canal de El Villar y el Canal de El Atazar unen sus aguas en el depósito de Torrelaguna (depósito inferior del nudo de las Calerizas), donde encontramos la almenara de entrada al sifón del mismo nombre, desplazando así el Canal de El Atazar hacia el sur. El sifón de Torrelaguna permanece enterrado a su paso por los valles de San Vicente y Santa Lucía, a partir de ahí podemos ver parte del Canal serpenteando al margen derecho del arroyo de Malacuera (a cotas superiores del Canal Bajo), salvando el arroyo del Monte a través del sifón de la Aldehuela y bordeando el pueblo de El Molar hasta atravesar el río Guadalix mediante el sifón del mismo nombre que el río, llegando así a la almenara de Los Castillejos, donde recibe las aguas del Canal de El Vellón (el cual toma sus aguas del embalse de Pedrezuela). 
El Canal de El Atazar continúa su recorrido, atravesando el término municipal de San Agustín de Guadalix, salvando mediante acueductos (Arroyo Seco, Canto Blanco y Mojapan) los cerros, valles y barrancos de los arroyos que vierten sus aguas río Guadalix, hasta llegar al trasvase de La Parrilla, donde el Canal Alto y el Canal de El Atazar igualan cotas e intercambian sus aguas. A partir de este punto, el Canal de El Atazar continúa su recorrido vía sifones (especialmente, el sifón de la Parrilla) y acueductos (El Espinar, El Salobral y El Chaparral), hasta llegar a la Estación de Tratamiento de Agua Potable de Colmenar donde son tratadas sus aguas antes de incorporarse al sifón de Colmenar, gracias al cual el agua llega hasta el depósito de El Goloso. Parte del agua que llega al depósito se almacena, mientras que el resto se traspasa, vía conducciones (sifones soterrados, fabricados en hormigón armado y vibrado, de dos metros de diámetro) hacia el depósito de Plaza de Castilla.

Figura 8. Sifones, almenaras y acueductos.

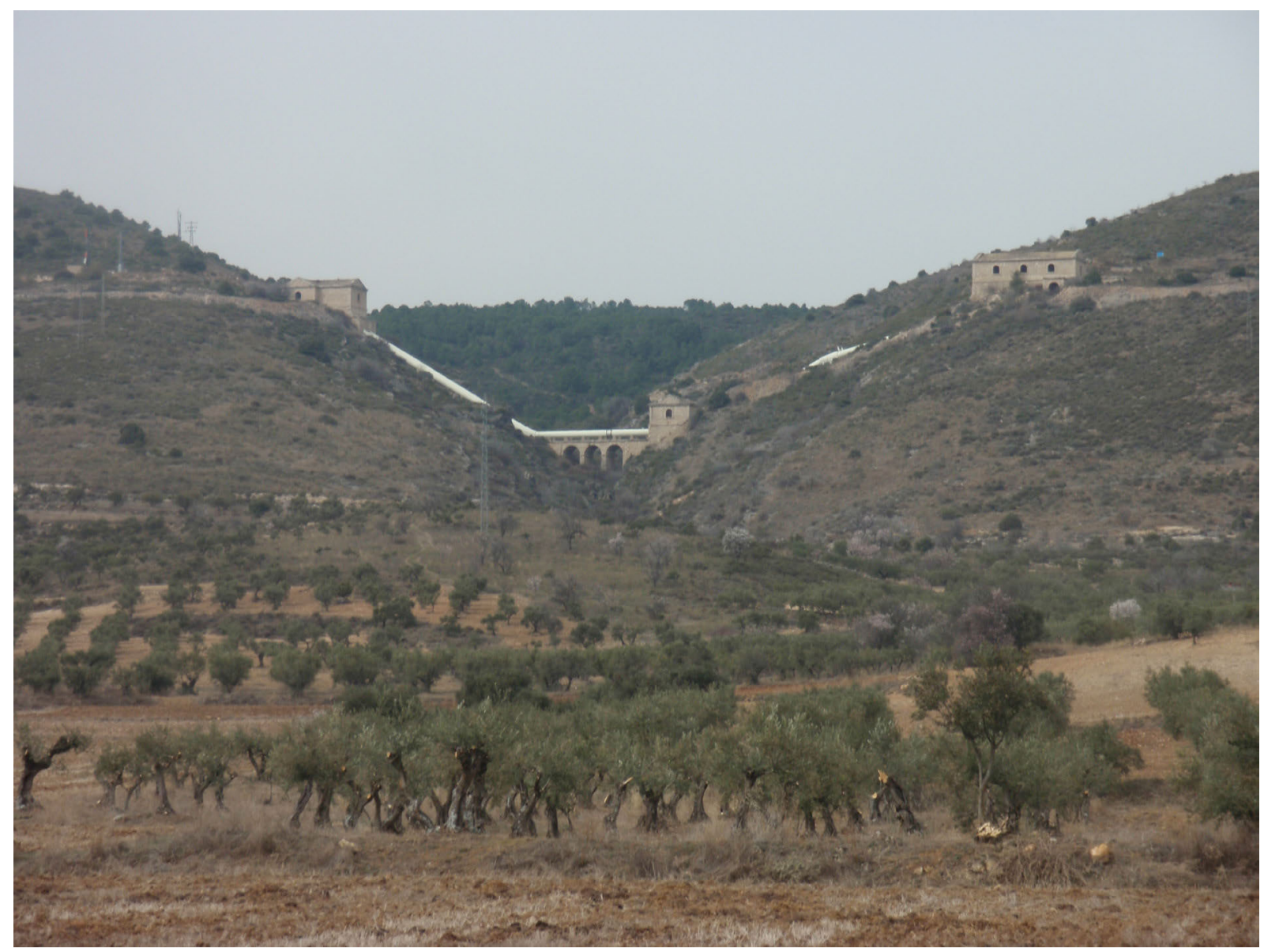

Fuente: José A. Sotelo Navalpotro.

Del mismo modo, se hace imprescindible describir las conducciones de los otros canales que conforman el Canal de Isabel II, a su paso por la Comunidad de Madrid: el Canal de La Parra, el Canal de El Villar, el Canal de el Jarama, el Canal de El Vellón, el Canal Alto y el Canal Bajo.

El Canal de La Parra, comenzó a funcionar en 1858 y es uno de los tramos del canal primitivo de abastecimiento de agua a Madrid. Tiene su inicio en el azud de La Parra, en el término municipal de Patones, donde toma sus aguas del embalse de El Atazar. Su recorrido finaliza en la almenara de El Empalme, en el término municipal de El Vellón, donde trasvasa sus aguas al Canal Bajo. En su tramo inicial, desde el azud de La Parra hasta el Pontón de la Oliva, el Canal serpentea el río, por un túnel excavado, sobre el que se asientan sifones que no han sido enterrados y permanecen al aire libre. A partir de ese punto, comienza su recorrido hacia la almenara de El Empalme. Sus conducciones se adaptan 
al medio, atravesando los barrancos vía sifones o sobre obras de mampostería, tales como acueductos, formando parte del propio paisaje (ver figura 9). En este tramo, al Canal de La Parra discurre en paralelo a los canales de El Atazar y el Canal de El Jarama, los cuales se encuentran a cotas más elevadas. Tras su paso por los barrancos de Las Cuevas, de Patones y San Román, el canal traza su recorrido hacia el sur, dejando atrás los cerros calizos mientras atraviesa los término municipales de Torremocha del Jarama y Torrelaguna -mediante un sifón constituido por un único tubo metálico-, hasta llegar a la almenara de El Empalme.

Figura 9. Acueductos del Canal de Isabel II.
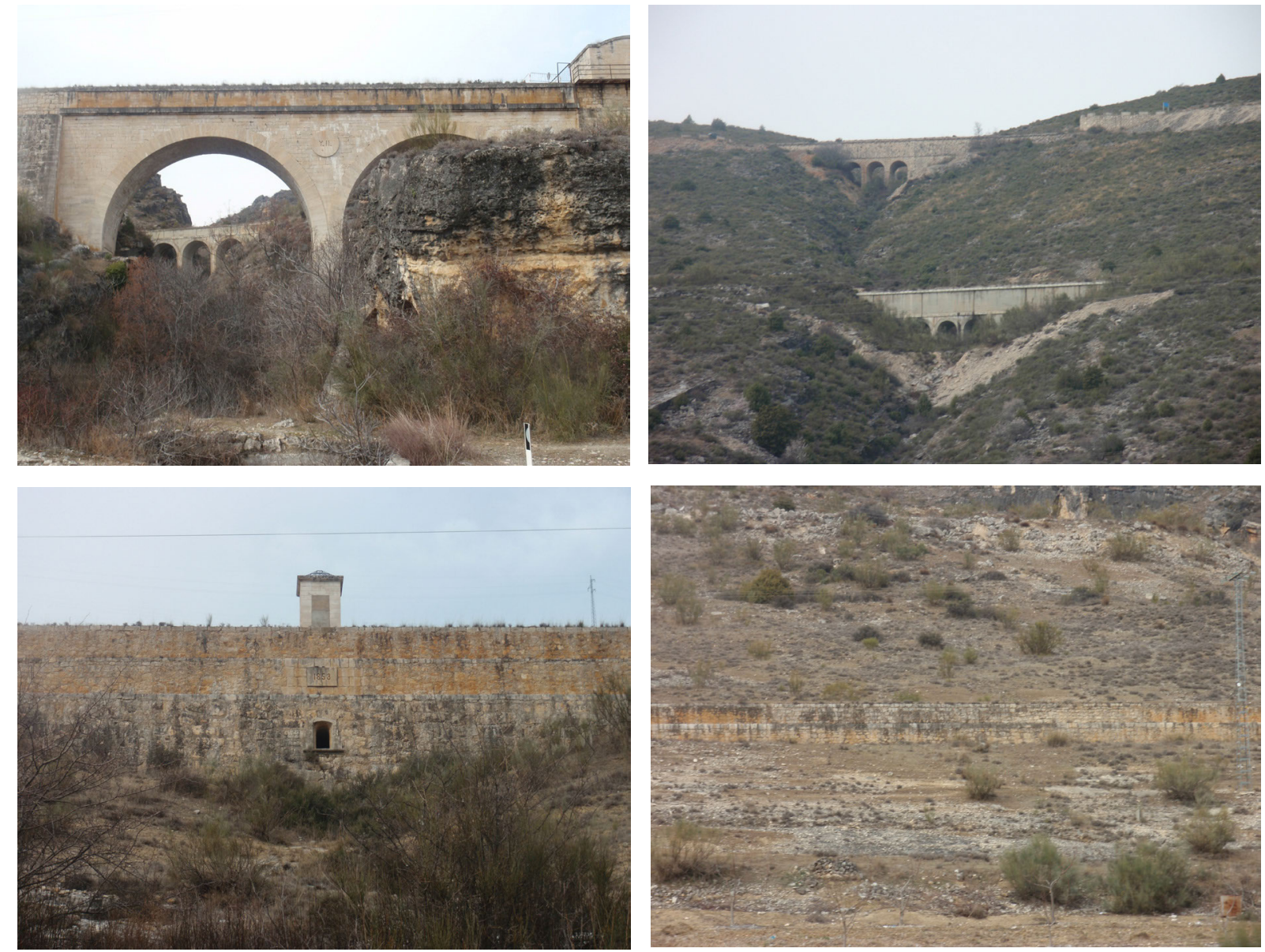

Fuente: José A. Sotelo Navalpotro.

El Canal de El Jarama, construido entre los años 1956 y 1960, toma sus aguas del embalse de El Vado (aprovechando así las aguas del río Jarama, que da nombre al canal) y las transporta hasta el depósito superior de Torrelaguna. El Canal está construido de hormigón armado y vibrado, con solera abombada y rematada en su parte superior por un arco de un metro y treinta centímetros de radio. En aquellas zonas en las que sus conducciones son visible (no han sido soterradas), estas han sido recubierta con piedra caliza labrada habiéndose adaptado perfectamente al medio en el que ha sido construida, confiriéndole un aspecto característico. Al igual que los canales de El Atazar y el de La Parra, atraviesa los cerros y sus barrancos mediante sifones construidos con dos tubos metálicos de un metro y medio de diámetro que parten siempre de una almenara de entrada hasta una almenara de salida. Su recorrido, desde el Pontón de la Oliva, transcurre en paralelo al Canal de El Atazar hasta llegar al depósito de Torrelaguna. Dada la accidentada topografía del recorrido, el canal tiene múltiples tramos, hasta treinta y cinco en túnel en su trazado original, a cielo abierto y en sifón.

De menor recorrido, pero no por ello de menor importancia, encontramos el Canal de El Villar. 
Construido en el año 1912, une el embalse de El Villar, en el término municipal de El Berrueco, con el depósito superior del nudo de Calerizas situado en Torrelaguna (donde se construyó una Estación de Tratamiento de Agua Potable, en el año 1967). El canal está construido con solera y bóveda de hormigón, mientras que los hastíales son de mampostería. A su vez, cabe destacar que, entre sus conducciones encontramos ocho almenaras, entre las que destacan la de Matamulos (a su paso de la cuenca del Lozoya a la del arroyo de San Vicente); cinco pontones; tres acueductos, de los que el de La Alameda es considerado uno de los más importantes y diez túneles sobre los que discurren sifones tintados y, perfectamente camuflados en su entorno.

Por último, con el fin de enlazar el embalse de Pedrezuela, en el municipio de El Vellón, con el Canal de El Atazar, en los Castillejos, se construyó en el año 1967, El Canal de El Vellón. Este, discurre en paralelo al Canal Alto, en el margen derecho del río Guadalix, alternando tramos del canal al aire libre, con túneles, a través de un único sifón denominado Labajo, salvan barrancos a la par que mediante acueductos como el de Cegrí.

\subsection{El impacto ambiental de Azudes, Almenaras y Sifones, en el ámbito rural}

Sin lugar a dudas, el análisis de la integración de estas infraestructuras en el paisaje podemos realizarlo siguiendo el esquema recogido en la matriz de interacciones simples y por etapas de proyectos hidráulicos (ver figura 10).

Figura 10. Matriz de interacciones simples y por etapas para proyectos hidráulicos.

\begin{tabular}{|c|c|}
\hline $\begin{array}{c}\text { Actividades de la construcción } \\
\text { y de la explotación (eje de las x) }\end{array}$ & $\begin{array}{l}\text { Atributos ambientales } \\
\text { (eje de las y) }\end{array}$ \\
\hline $\begin{array}{l}\text { Clareos } \\
\text { Talas } \\
\text { Retirada tierra vegetal } \\
\text { Excavación } \\
\text { Apilado materiales } \\
\text { Carga-descarga } \\
\text { Acumulación de material } \\
\text { Nivelación } \\
\text { Compactación } \\
\text { Eliminación de materiales } \\
\text { Voladuras } \\
\text { Hormigonado } \\
\text { Explanación } \\
\text { Levantamiento edificaciones } \\
\text { Traslado edificaciones } \\
\text { Demolición pavimentos } \\
\text { Plantas de lotes y agregación } \\
\text { Edificaciones temporales } \\
\text { Mantenimiento de vehículos y equipos } \\
\text { Restauración } \\
\text { Llenado del vaso } \\
\text { Operaciones de control de avenidas }\end{array}$ & $\begin{array}{l}\text { Calida del aire } \\
\text { Microclima } \\
\text { A. Movimiento de masa de aire } \\
\text { B. Temperatura del aire } \\
\text { C. Humedad relativa } \\
\text { D. Insolación } \\
\text { Condiciones del suelo } \\
\text { A. Temperatura } \\
\text { B. Humedad en el suelo } \\
\text { C. Estructura del suelo } \\
\text { D. Flora d el suelo } \\
\text { E. Fauna del suelo } \\
\text { Relaciones ecológicas } \\
\text { A. Ecosistemas terrestres } \\
\text { 1. Cambios en ecoestructura } \\
\text { 2. Estructura trófica } \\
\text { 3. Contaminación del suelo } \\
\text { 4. Ecotipos raros o únicos } \\
\text { 5. Diversidad de ecotipos } \\
\text { 6. Ciclos bioquímicos } \\
\text { B. Ecosistemas acuáticos } \\
\text { Fauna } \\
\text { A. Animales terrestres } \\
\text { 1. Mamíferos } \\
\text { 2. Aves } \\
\text { 3. Otros vertebrados } \\
\text { 4. Insectos } \\
\text { 5. Otros invertebrados } \\
\text { 6. Especies raras y en peligro } \\
\text { 7. Diversidad de especies, etc. } \\
\text { 8. Especies molestas } \\
\text { B. Animales acuáticos } \\
\text { Flora A. Plantas terrestres } \\
\text { B. Flora acuática } \\
\text { (a) }\end{array}$ \\
\hline
\end{tabular}




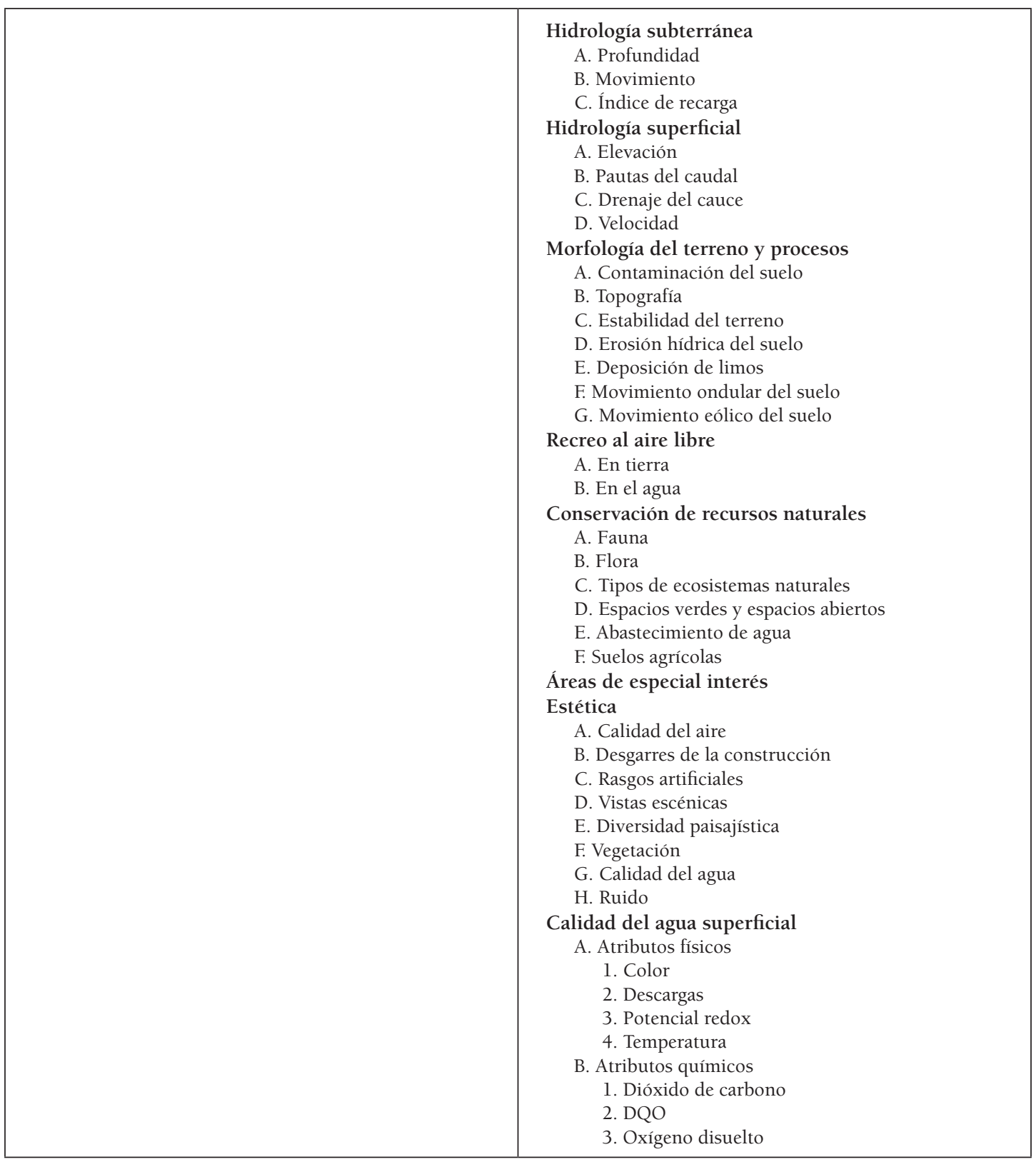

Fuente: Canter, L.W. (2007), adaptado de Jhonson y Bell (1975).

En este sentido, tal y como hemos podido comprobar en los epígrafes anteriores, a la largo de los últimos ciento cincuenta años, en la que otrora se denominara "Sierra pobre de Madrid", se ha ido conformando un nuevo paisaje, que es el de los embalses, canales, azudes, almenaras y sifones, unido al intenso desarrollo constructivo experimentado en las últimas décadas, que además de incrementar las exigencias ciudadanas de cumplimiento de la legalidad urbanística y de elaboración de políticas más restrictivas, ha espoleado simultáneamente una nueva reivindicación social, la de la integración paisajística de las construcciones, con una población que desarrolla su ocio en estos espacio, conformando lo que podríamos denominar como nuevo paisanaje (todo ello, sin olvidarnos que la integración paisajística, entendida como intervención pública, tiene un grado de desarrollo aún incipiente en el espacio rural, al menos en nuestro país).

El intenso desarrollo "constructivo" experimentado, además de incrementar las exigencias ciudadanas de cumplimiento de la legalidad urbanística y de elaboración de políticas más restrictivas, ha espoleado simultáneamente una nueva reivindicación social, la de la integración paisajística de las construcciones, 
demanda fundamentada, más allá del aumento de la densidad de edificaciones, en los discutibles emplazamientos elegidos y, particularmente, en las controvertidas modalidades tipológicas empleadas. En los espacios rurales, por otra parte, el contraste se agudiza de forma sensible por la introducción de tipologías arquitectónicas de inspiración urbana, tradicionalmente ausentes de este medio.

La integración paisajística, entendida como intervención pública, tiene un grado de desarrollo aún incipiente en el espacio rural, al menos en nuestro contexto espacial. Por el contrario, fue en las zonas urbanas donde este modelo de gestión territorial surgió y donde su trayectoria cuenta con un mayor recorrido. En nuestra zona de estudio nos encontramos con que la integración en el paisaje de almenaras, azudes y sifones, se realiza sobre una realidad geomorfológica en la que se desarrollan dos formas dominantes: una antigua superficie plana, de erosión, que se refleja en una línea de cumbres planas, desarrollada en los materiales mesozoicos y una cuesta estructural que, desde la superficie de erosión citada, desciende hasta la llanura aluvial del río Jarama que corre a su pie (figura 11).

Figura 11 .

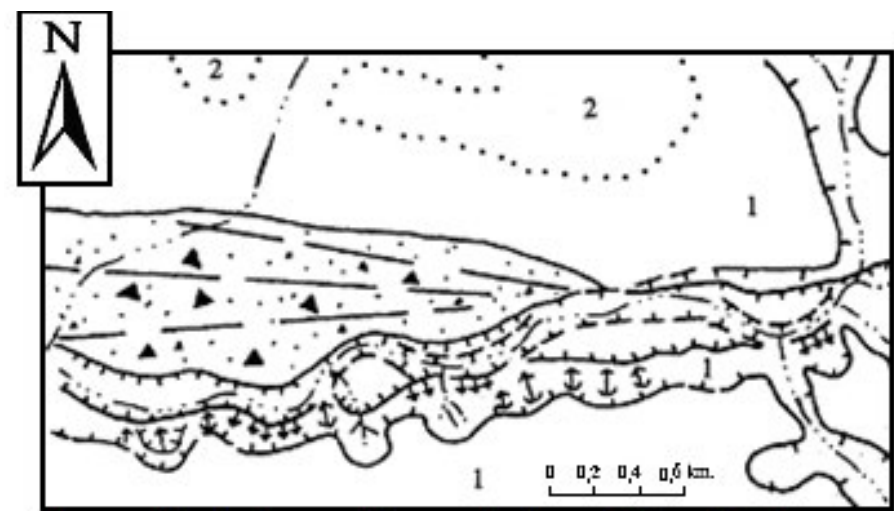

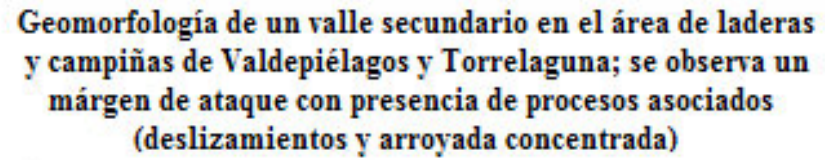

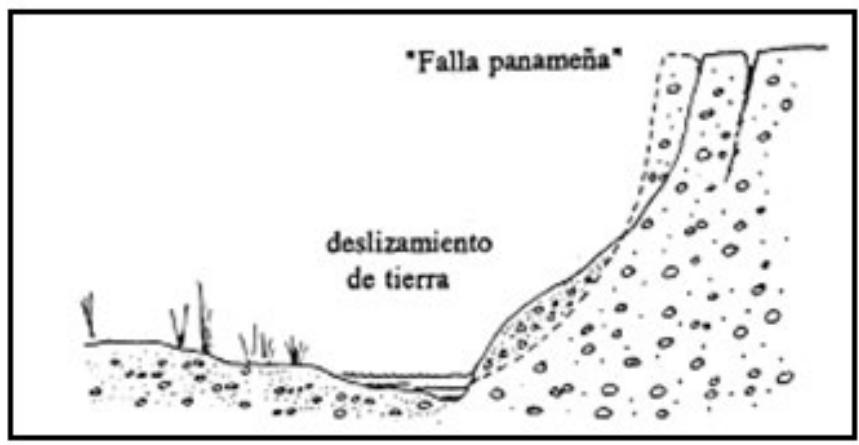

El retroceso de las laderas del valle se realiza a partir de desplazamientos asociados a la formación de "fallas panameñas"
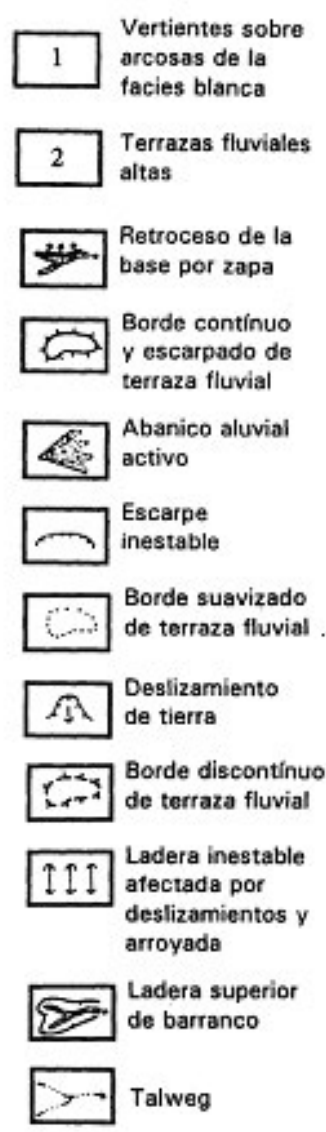

Fuente: Torres, T. et al., (2005). Génesis y edad del karst del Cerro de la Oliva y la Cueva del Reguerillo (Torrelaguna, Madrid).

De esta forma, a la compleja realidad geomorfológica, en la conformación del paisaje resultante, se le añaden construcciones entre las que se encuentran infraestructuras que, en algunos casos, tienen más de un siglo y medio de existencia. Esto se ve complementado por el carácter del paisaje en el que se integran las conducciones, marcada por la variedad e intensidad de los rasgos paisajísticos más los denominados elementos básicos del paisaje: forma, línea, color y textura. De hecho, en ocasiones, la adaptación al medio es superior en las mencionadas conducciones, que en otras realizadas muy posteriormente (como podemos observar en la figura 12). 
Figura 12. Depósito elevado en Patones.

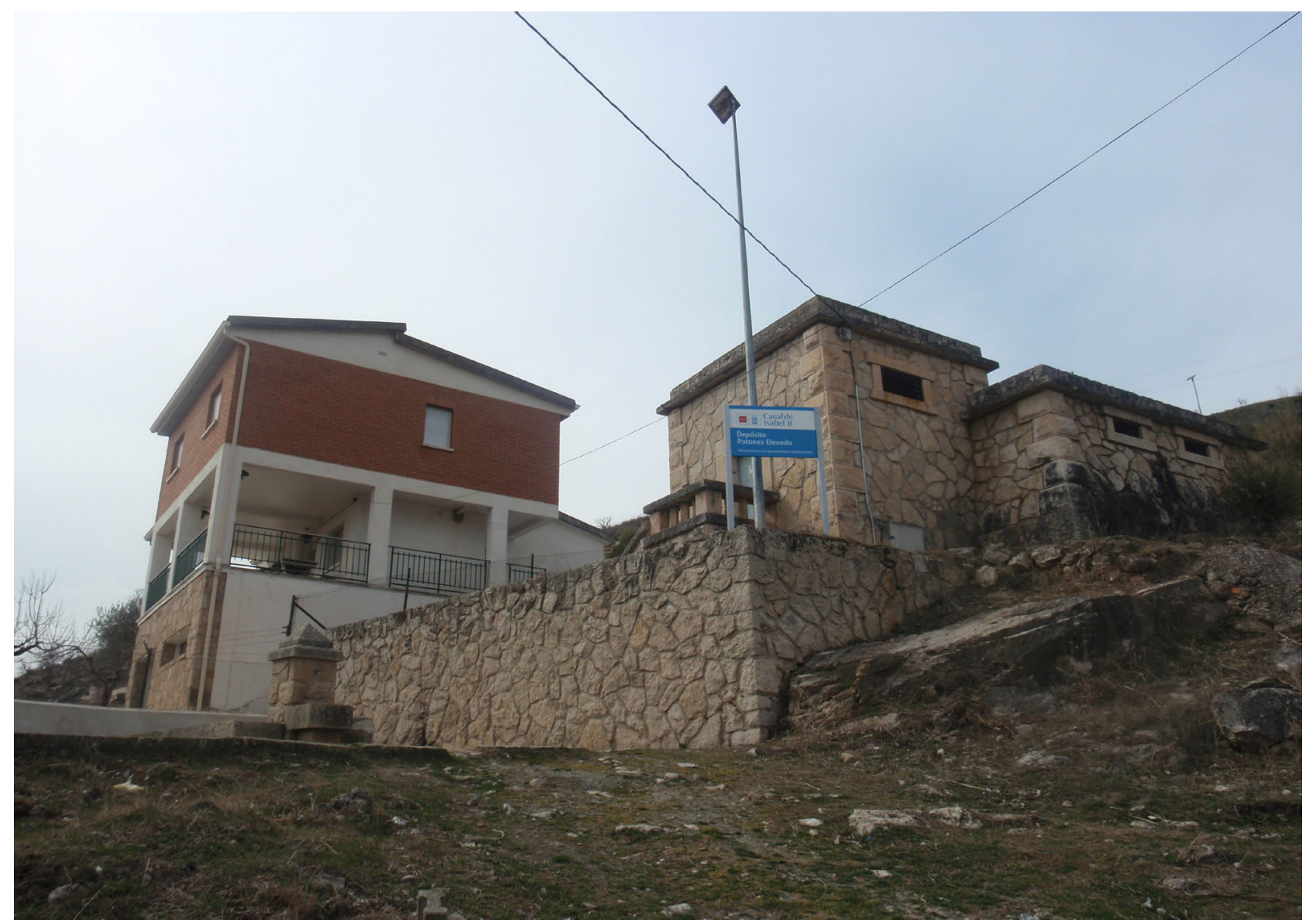

Fuente: José A. Sotelo Navalpotro.

Sobre el barranco de Patones, en el término municipal que le da nombre, encontramos la almenara y los sifones de Patones. Pertenecientes todos ellos al Canal de El Atazar. Los sifones salvan los barrancos que separan los cerros calizos (barranco de Patones, de las Cuevas y de San Román, principalmente). Estos están construidos de hormigón armado, tintados de color verde en aquellas zonas en las que han quedado al descubierto, ya que la mayor parte de los sifones del el Canal de El Atazar han sido enterrados.

La vegetación es, fundamentalmente, matorral, con lo que la roca caliza queda al descubierto en la mayor parte de la topografía. Por ello, la coloración verde de los sifones y la construcción de la almenara y el acueducto con mampostería de roca caliza, favorecen la integración de dichos elementos en el entorno sobre el que se asientan (ver figura 13).

El impacto visual que genera cualquier infraestructura, como los azudes, queda matizado por el propio medio natural que lo envuelve, y acaba absorbiendo a las propias obras humanas. Un buen ejemplo lo encontramos en las dos imágenes del azud y del sifón de Valdentales, pertenecientes al Canal de El Atazar. Se localizan en el término municipal de Patones y reciben su nombre del arroyo sobre el que se asientan. En este tramo, el canal transcurre por un túnel a presión de tres metros de diámetro y 3.383 metros de longitud. Los tubos de los sifones miden dos metros de diámetro y son fabricados en hormigón armado de color "beige", y destacan sobre ellos la construcción de un pozo Ranney, hoy día en desuso, que drenaba el agua del río (ver figura 14).

Próxima a la presa del Pontón de la Oliva, en el término municipal de Patones, nos encontramos con ruinas de diferentes construcciones que en el pasado servían de complemento a una ocupación humana que encontró en estos terrenos las aguas imprescindibles para el abastecimiento de la ciudad de Madrid. Los materiales utilizados en la construcción de ermitas o parideras se usarán con el mismo impacto visual en las almenaras o sifones, que llegan a conformar, en la actualidad, verdaderos recursos estéticos (ver figura 15). 
Figura 13. Almenaras, sifones y acueductos.

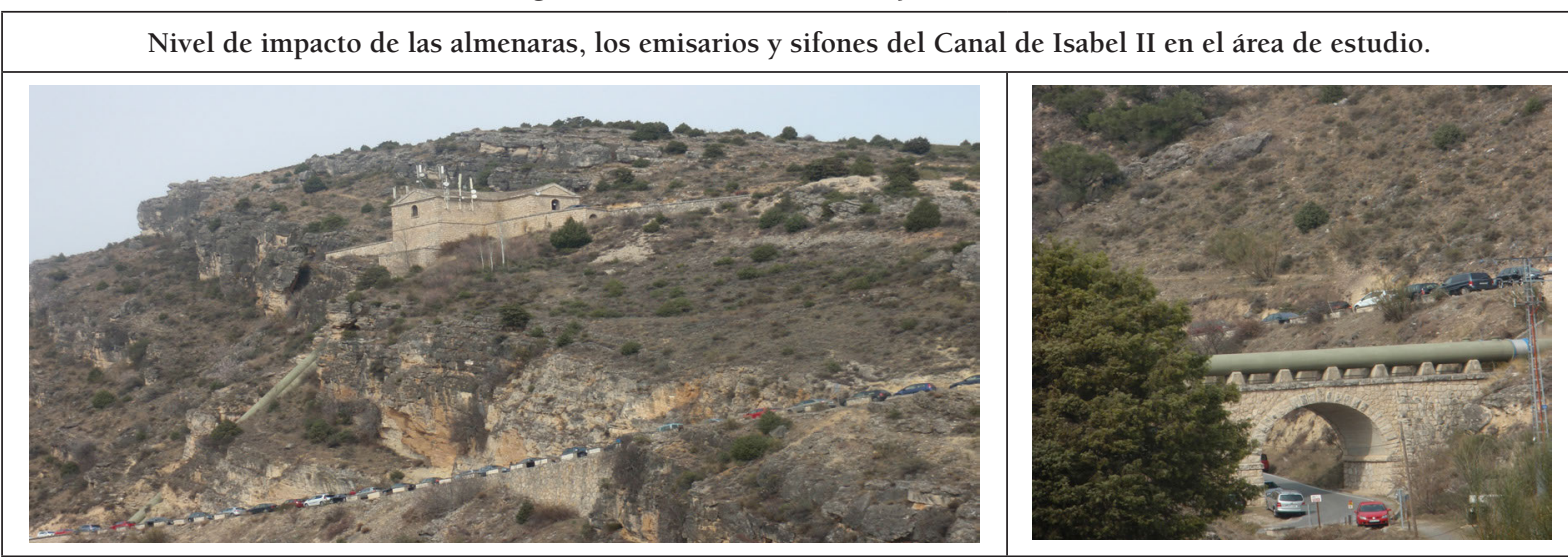

Las infraestructuras aparecen perfectamente adaptadas al medio. Tanto es así, que le han conferido un carácter concreto al propio paisaje. Dicho carácter visual está formado por cuatro elementos básicos:

a) La "forma" viene marcada por la agregación de distintos elementos que se perciben, tales como la almenara, los sifones, el acueducto que sostiene el sifón, los coches aparcados y transitando por la vía, las señales de tráfico, matorrales, la roca..

b) La "línea", en la que la horizontalidad de la construcción de la almenara o del acueducto por el que transcurre el sifón y la verticalidad de los sifones complementan el terreno fallado.

c) El "color" con el que se han pintado los sifones le permiten adaptarse perfectamente al terreno y, de igual modo, los materiales de construcción empleados, tanto en la almenara como en el acueducto (piedra caliza y caliza dolomítica) favorecen la integración de todos ellos en el medio sobre el que se asientan. A esto último se le denomina "textura".

El impacto visual contribuye al logro de una reducción en los valores escénicos por lo que, tal y como podemos ver en las imágenes anteriores, contrasta más las infraestructuras viales, y los automóviles aparcados en las mismas, que las propias canalizaciones y los sifones.

Figura 14. Azudes y sifones.

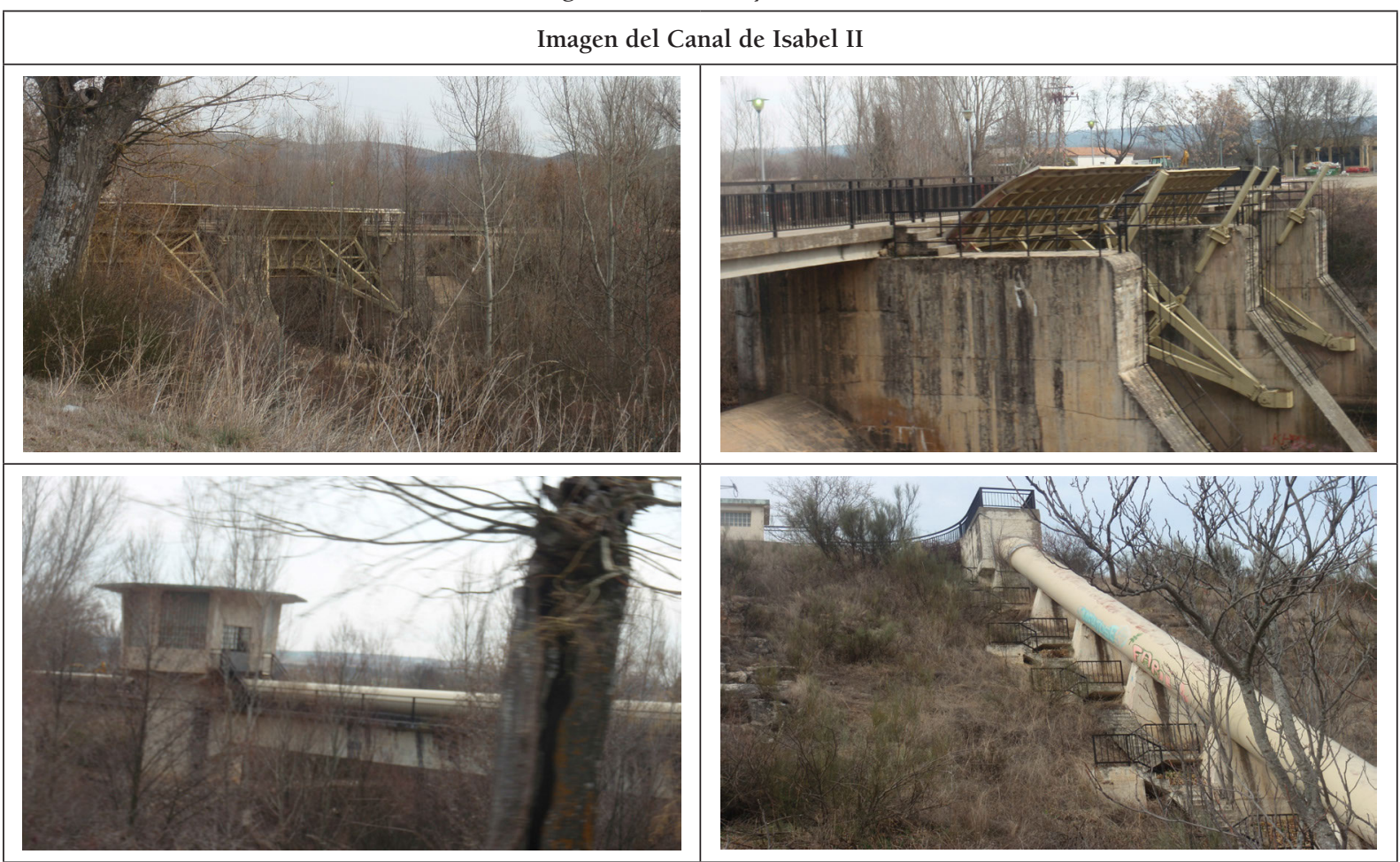

La "forma" está constituida por seis elementos básicos: el primero y principal la presa del Canal de Isabel II, sobre la que transcurre una carretera de acceso a los pueblos cercanos; en segundo lugar, la alameda y los; los cerros calizos; el sifón de Valdentales, a través del cual se transporta el agua; el pozo Ranney; y, por último, las infraestructuras, señales de tráfico, farolas y edificaciones.

La "línea" se ve claramente marcada por la horizontalidad de la construcción del azud que mantiene la tendencia general del terreno y la verticalidad del sifón que se adapta a las condiciones del mismo.

En cuanto a la "textura" y el "color", el empleo de materiales metálicos pintados en "beiges" y el uso de hormigón tintado de colores claros favorecen el camuflaje de las construcciones y, de igual modo, la integración de dicho azud, del pozo y del sifón en el propio paisaje. Cabe destacar la impercepción del azud en su entorno, por lo que su impacto visual es prácticamente nulo. 
Figura 15. Almenaras y sifones.

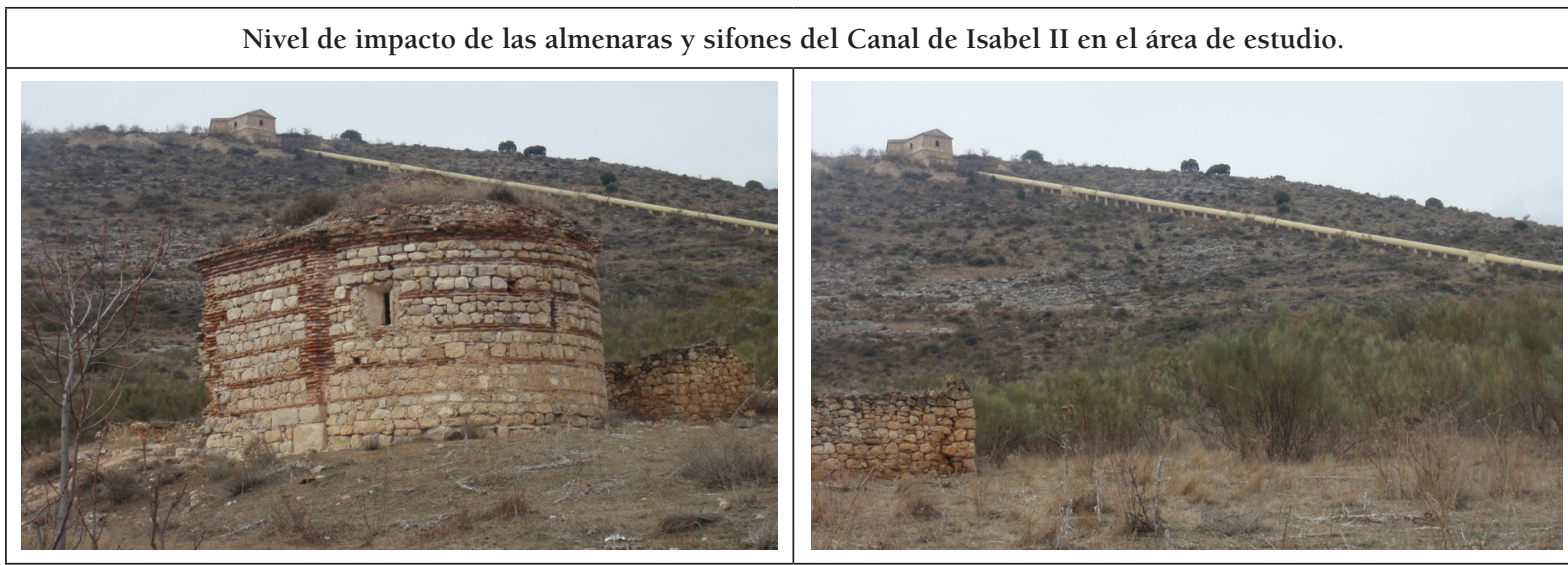

Almenara y sifones se nos muestran perfectamente adaptados a un medio al que confieren el valor propio de la particularidad de una composición marcada por la variedad e intensidad de los rasgos paisajísticos, alcanzándose una notable compatibilidad visual (sin lugar a dudas, estas infraestructuras se nos muestran visualmente adaptadas a su entorno). Dicho carácter visual se nos presenta formado por cuatro elementos básicos:

a) La "forma" viene marcada por la agregación de distintos elementos que se perciben, tales como la almenara, los sifones, el retamal y la ermita que aparece en primer plano.

b) La "línea" en la que la horizontalidad de la construcción de la almenara y la verticalidad de los sifones complementan el paisaje de cerros, retamales y la ermita.

c) El "color" con el que se han pintado los sifones le permiten adaptarse perfectamente al terreno por el que transcurren y, de igual modo, los materiales de construcción empleados tanto en la almenara como en la ermita (piedra caliza y caliza dolomítica) favorecen la integración de todos ellos en el medio sobre el que se asientan.

Por otra parte, no son pocos los rasgos culturales del medio ambiente de nuestra zona de estudio, que consiguen reacciones sensoriales de aprecio por parte del observador. Un buen ejemplo lo encontramos en los sifones de los Canales de La Parra y el Jarama, al noreste del término municipal de Patones. Tal y como podemos ver en las fotografías, los sifones se componen de dos tubos de hormigón armado y vibrado, de dos metros de diámetro que atraviesan el terreno desde una almenara de entrada hacia otra almenara de salida. En inicio, los sifones estaban construidos con palastro, recubiertos con hormigón y rellenados interiormente con cemento.

Los sifones que conforman todos y cada uno de los canales del Canal de Isabel II, se encuentran tintados de colores verdes o "beiges" clarito, lo que favorece, no sólo el camuflaje, sino la adaptación de los mismos a las zanjas sobre las que se asientan y discurren. De igual modo, la propia vegetación (principalmente los retamares, tomillares y romerales) llegan a tapar por completo los sifones, quedando así integrados dentro del propio paisaje (ver figura 16).

No debemos olvidarnos que el impacto ambiental de las conducciones queda matizado por el hecho de que el paisaje puede llegar a generar un verdadero escenario en el que las infraestructuras culturales, son algo más que una simple denominación. El paisaje primigenio, en la actualidad, está alterado, transformado y conformado por unas infraestructuras en las que sobre la presa y otras edificaciones destaca la incorporación al territorio del sifón, en este caso, del Pontón de la Oliva (ver figura 17).

Los fenómenos anteriormente descritos se repiten en las siguientes imágenes. Éstas muestran las almenaras del Canal del Jarama, al noreste del término municipal de Patones. Tal y como podemos ver en las fotografías, las almenaras reciben dos tubos de hormigón armado y vibrado, de dos metros de diámetro que atraviesan el terreno desde una almenara de entrada hacia otra almenara de salida. Dichas almenaras, tanto de entrada como de salida, que unen todos y cada uno de los sifones del Canal de Isabel II, han sido construidos con la roca caliza sobre la que se asientan, lo que favorece, no sólo el camuflaje, sino la adaptación de los mismos al propio terreno. De igual modo, la propia vegetación (principalmente los retamales, tomillares y romerales) llegan a tapar por completo los sifones, quedando así integrados dentro del propio paisaje (ver figura 18). 
Figura 16. Conducciones: Los sifones.

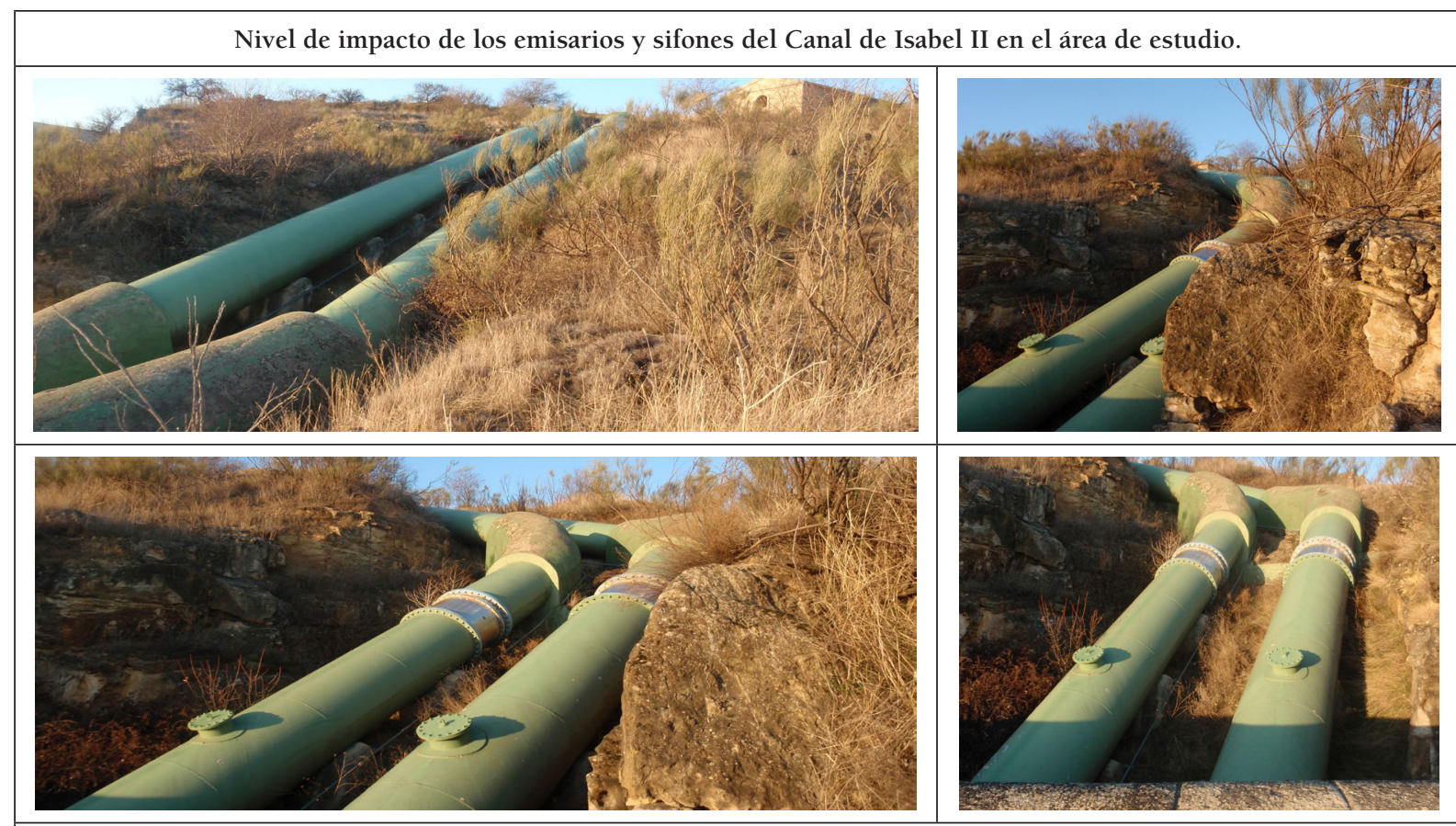

Tal y como podemos ver en estas imágenes, las infraestructuras aparecen perfectamente adaptadas al medio. La "forma" viene marcada por la agregación de tres elementos principales; los sifones, la vegetación (retamas, tomillos, romeros...) y la roca caliza. En cuanto a la "línea", la verticalidad de los sifones se adapta totalmente a las condiciones físicas del terreno, serpenteando la roca caliza y salvando las pendientes. El "color" y la "textura", como se señala en la parte superior de la ficha, favorecen, no sólo la adaptación de las infraestructuras al medio, sino que le dan un valor intrínseco, permitiéndoles ser un elemento integrado del mismo.

Figura 17. Presa de "el Pontón de la Oliva" y sus sifones.
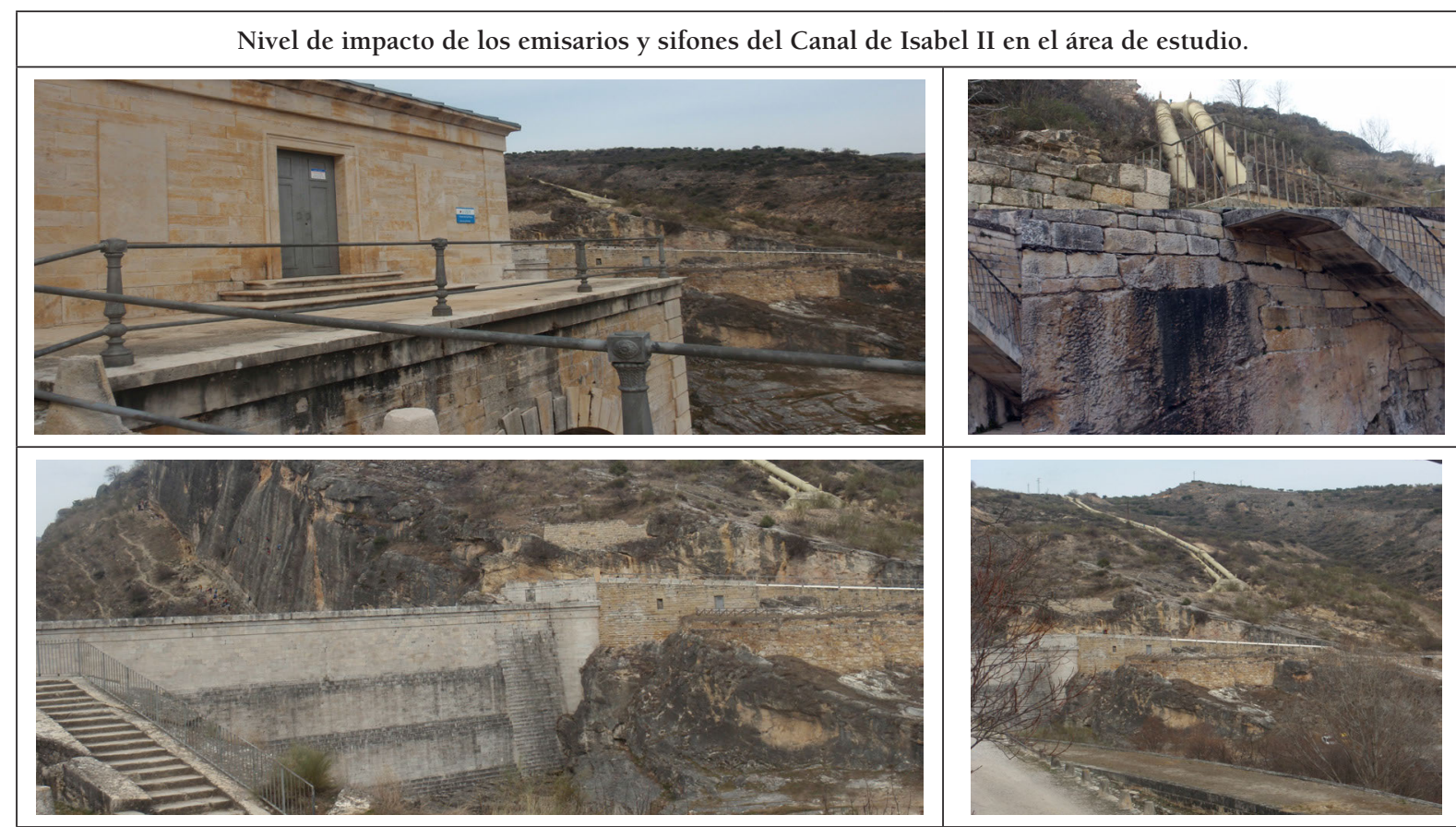

a) La "forma" viene marcada por la presa y el sifón de El Pontón de la Oliva, las infraestructuras propias de la presa, la vegetación (retamales y algún enebro), la roca caliza y los postes de la luz.

b) La "línea" en la que la horizontalidad de la construcción de la almenara o del acueducto por el que transcurre el sifón y la verticalidad de los sifones complementan el terreno fallado.

c) El "color" y la "textura" vienen marcados por el color beige clarito con el que se han pintado los sifones de hormigón armado, que les permiten adaptarse perfectamente al terreno por el que transcurren y, de igual modo, los materiales de construcción empleados en la presa (piedra caliza y hormigón, principalmente) favorecen la integración de todos ellos en el medio sobre el que se asientan. 
Figura 18. Conducciones: Sifones y almenaras.

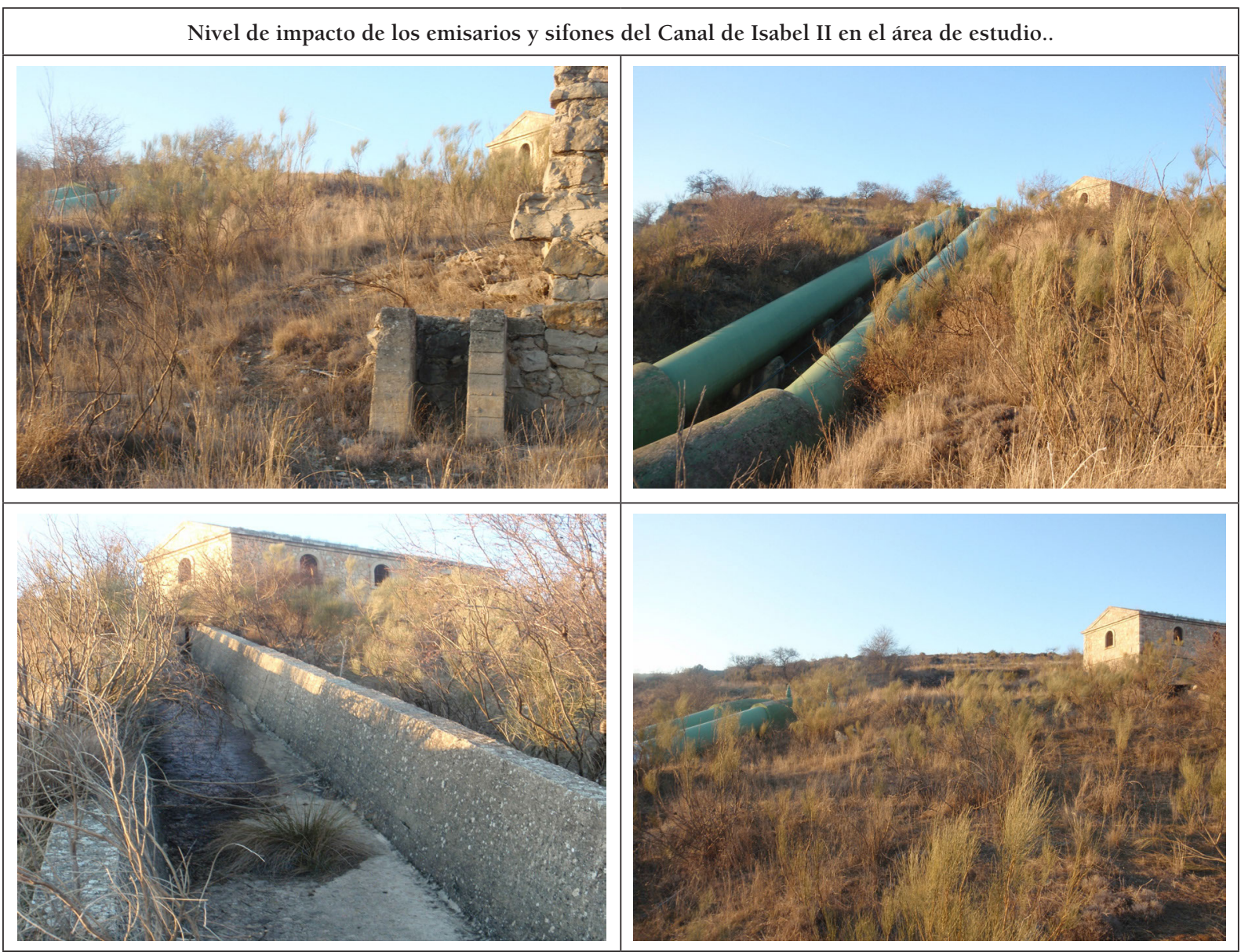

La "forma" viene marcada por la agregación de cuatro elementos; las almenaras, los sifones, la vegetación (retamas, tomillos, romeros...) y la roca caliza. En cuanto a la "línea", la horizontalidad de las almenaras se adapta totalmente a las condiciones físicas del terreno, localizadas, fundamentalmente en la parte superior de los cerros y barrancos. El "color" y la "textura" favorecen, no sólo la adaptación de las infraestructuras al medio, sino que le dan un valor intrínseco, permitiéndoles ser un elemento integrado del mismo. Las almenaras han sido edificadas con muros de mampostería de roca caliza, extraída, en la mayor parte de los casos, del propio lugar sobre el que se asientan.

Hemos señalado en nuestro estudio que, los sifones y las almenaras se ubican sobre los cerros calizos mesozoicos. Otras formas de relieve son las terrazas fluviales y los conos de deyección. Sistemas escalonados de terrazas fluviales se asocian al río Jarama. Se trata de terrazas asimétricas, excelentemente desarrolladas en la margen izquierda del río, prácticamente inexistentes en la margen derecha. En esta última zona, extensos conos de deyección, asociados a las desembocaduras de los barrancos que atraviesan la orla mesozoica de cerros calizos, componen formas características. La presencia a techo de la serie mesozoica, de niveles muy potentes de rocas carbonatadas con intercalaciones margosas, propició, y propicia, el desarrollo de procesos gravitacionales, siendo abundantes los desplomes. Entre ellos, el fenómeno más importante fue un gigantesco deslizamiento plano de los niveles superiores del Cretácico a favor de un nivel margoso (ver figura 19).

Llegados a este punto, debemos de ser conscientes que el concepto de integración paisajística, así como la misma noción de integración, se ha convertido en un argumento de gran interés y utilidad, pero en muchas ocasiones su imagen positiva ha supuesto su utilización indiscriminada y abusiva. Sin lugar a dudas no es el caso de almenaras y sifones que en el Canal de la Parra se presentan perfectamente integrados en el propio paisaje (ver figura 20). 
Figura 19. Sifones y almenaras de "el Canal del Jarama".

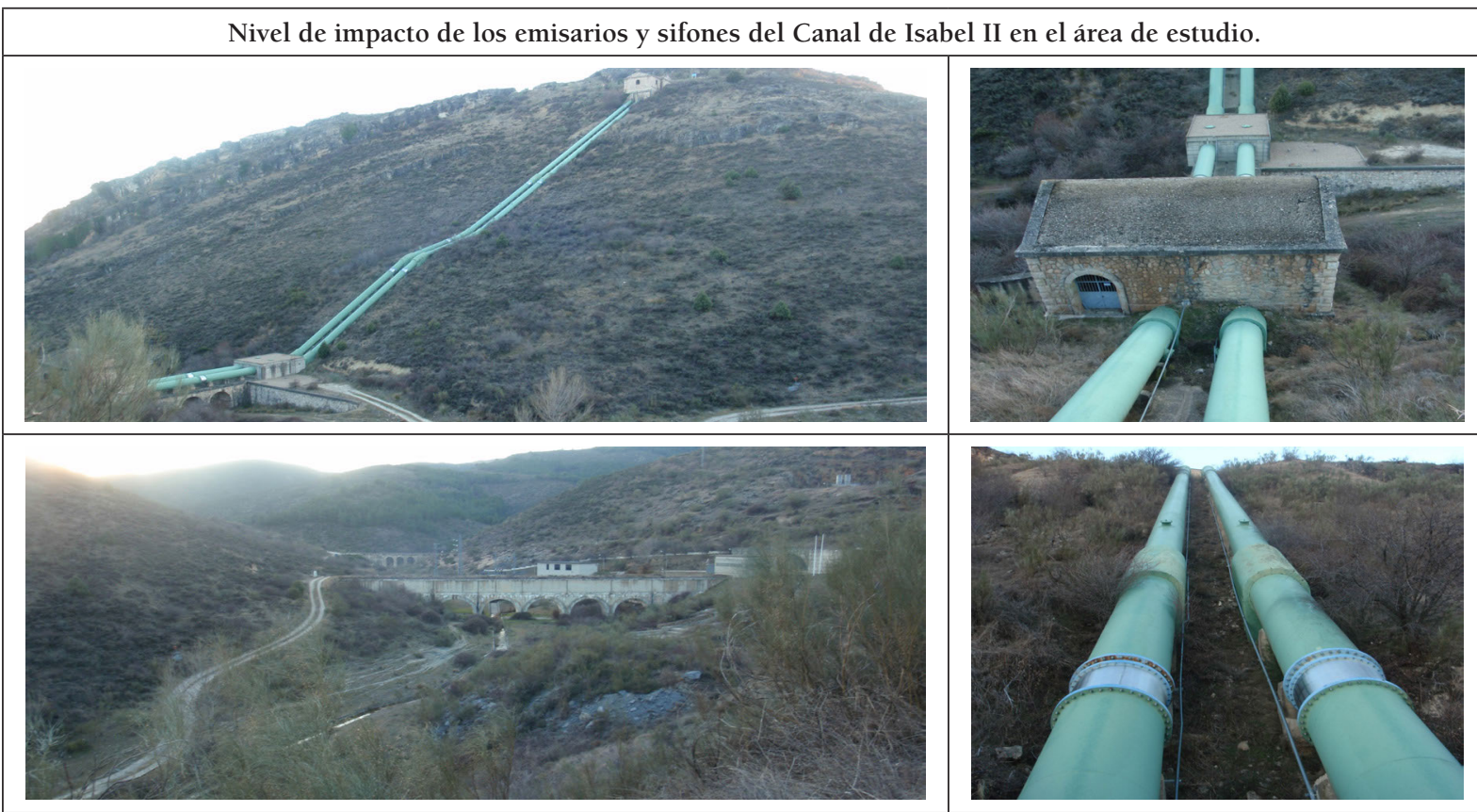

Las infraestructuras aparecen perfectamente adaptadas al medio. Tanto es así, que le han conferido un carácter concreto al propio paisaje. Dicho carácter visual está formado por cuatro elementos básicos:

a) La "forma" viene marcada por la agregación de distintos elementos que se perciben, tales como la almenara, los sifones, el acueducto que sostiene el sifón, matorrales, la roca.

b) La "línea" en la que la horizontalidad de la construcción de la almenara o del acueducto por el que transcurre el sifón y la verticalidad de los sifones complementan el terreno fallado

c) El "color" con el que se han pintado los sifones le permiten adaptarse perfectamente al terreno por el que transcurren y, de igual modo, los materiales de construcción empleados tanto en la almenara como en el acueducto (piedra caliza y caliza dolomítica) favorecen la integración de todos ellos en el medio sobre el que se asientan.

d) La "textura" viene marcada, fundamentalmente, por el uso de piedra caliza para la construcción de la almenara y el acueducto.

Figura 20. Impacto visual de almenaras y sifones de el Canal de la Parra.

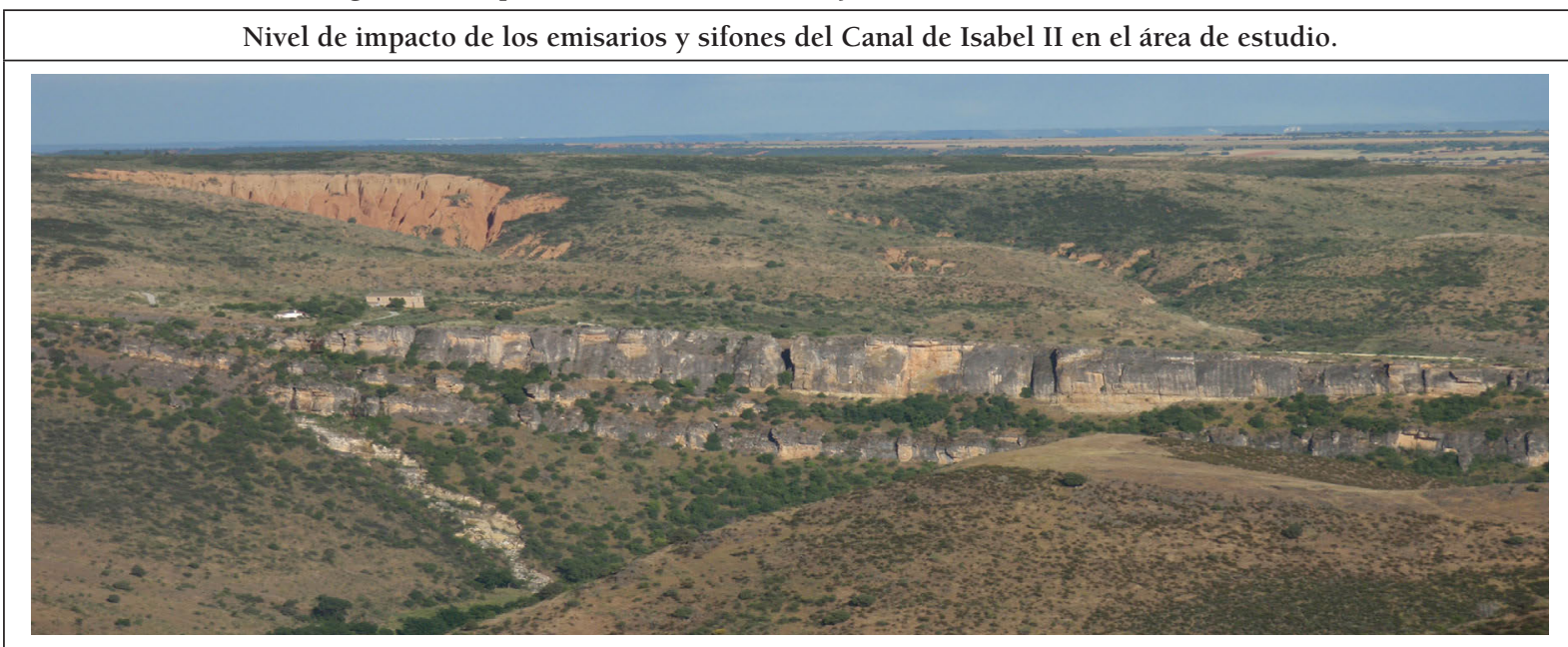

Las infraestructuras se nos presentan integradas en un medio cuyo paisaje nos presenta una vegetación muy degradada, en la que la masa forestal primigenia ha sido sustituida por coscojares, tomillares, jarales o brezales, conjunto de vegetación que se corresponde con las diferentes etapas de sustitución de la vegetación climotófila arbolada. De hecho, las conducciones discurren entre formaciones que se comportan en áreas como las recogidas en las imágenes como verdaderas comunidades topográficas permanentes. Tanto es así, que le han conferido un carácter concreto al propio paisaje. Dicho carácter visual está formado por cuatro elementos básicos:

a) La "forma" viene marcada por la agregación de distintos elementos que se perciben, tales como la almenara, los sifones, los matorrales, la roca caliza o las cárcavas. Sin lugar a dudas, nos encontramos con un escenario visual equilibrado, en el que los elementos provenientes en la construcción de infraestructuras están perfectamente integrados.

b) La "línea" en la que la horizontalidad de la construcción de la almenara o de los sifones complementan el terreno escarpado.

c) El "color" con el que se han pintado los sifones le permiten adaptarse perfectamente al terreno por el que transcurren y, de igual modo, los materiales de construcción empleados en la almenara (piedra caliza y caliza dolomítica) favorecen la integración de todos ellos en el medio sobre el que se asientan.

d) La "textura" viene marcada, fundamentalmente, por el uso de piedra caliza para la construcción de la almenara. 


\section{CONCLUSIONES}

A lo largo de las páginas anteriores se ha puesto de manifiesto cómo la integración paisajística -en el ámbito de las intervenciones públicas-, tiene un grado de desarrollo aún incipiente en el espacio rural, al menos en nuestro contexto espacial (si bien, dicho modelo de gestión territorial surgió y se desarrollo de manera más considerable en las zonas urbanas). Tal y cómo hemos podido ver, estudiar y analizar, en nuestra zona de estudio nos encontramos con que la integración en el paisaje de almenaras, azudes y sifones, se realiza sobre una realidad geomorfológica marcada por una antigua superficie plana, de erosión, y, una cuesta estructural que, desde la superficie de erosión citada, desciende hasta la llanura aluvial del río Jarama, que corre a su pie. Va a ser sobre esta realidad base de los paisajes primigenios, sobre la que se ha desarrollado la integración de las mencionadas infraestructuras.

De igual modo, en los últimos años, ha ido cobrando notable interés en la sociedad española y, concretamente, en la de Madrid, la problemática de la integración en el paisaje de las actividades humanas, especialmente a aquellas vinculadas a las infraestructuras del Canal de Isabel II. En cierta medida, la integración paisajística ha supuesto la incorporación de una nueva variante temática al interés social por el paisaje, trascendiendo y sumándose a la ya más consolidada preocupación por la conservación de los paisajes más valiosos. Aporta también una dimensión territorial más amplia, porque afecta o puede afectar al conjunto del territorio, al mismo tiempo que introduce una escala de análisis más cercana, abordando problemas concretos, y una evidente utilidad aplicada, ya que trata de prevenir o corregir impactos sobre el paisaje.

En definitiva, el análisis del impacto de las infraestructuras del Canal, en nuestro área de estudio, está marcada por la integración paisajística, entendida como una demanda social e institucional cada vez más consolidada, en el marco de la creciente consideración del paisaje como un recurso merecedor de protección y cuya puesta en valor puede contribuir de forma notable al desarrollo socioeconómico. En el caso de las conducciones del Canal de Isabel II, a través de aquella se palia el posible impacto de las infraestructuras. Por otra parte, la aplicación de una estrategia de integración paisajística constituye una herramienta de utilidad para la gestión del paisaje, especialmente para determinadas modalidades, como sucede con sifones, almenaras y azudes, de tal forma que las estrategias de adaptación o referenciación que se han aplicado a lo largo de las últimas décadas se han remitido al paisaje tomado como referente, abstrayendo los elementos alterados, alcanzando una integración paisajística entendida como una función activa en las políticas territoriales y asumiendo una especie de liderazgo en la restauración de estos paisajes, que hoy ya no se entenderían sin las referidas conducciones. Podemos finalizar, en lo referido a la integración de las infraestructuras históricas y su impacto sobre el medio, coincidiendo con Aristóteles que en su Ética a Nicómaco, afirma que es muy importante que "lo accesorio no resulte más abultado que las actividades".

\section{BIBLIOGRAFÍA}

AA.VV. (1987): La naturaleza de Madrid. Comunidad de Madrid. Consejería de Agricultura y Ganadería.

AA.VV. (2008): Atlas de medioambiente de la Comunidad de Madrid. Comunidad de Madrid. Consejería de Medio Ambiente y Ordenación del Territorio.

CANAL DE ISABEL II (2008): Memoria sobre la conducción de aguas a Madrid. Vicepresidencia primera y Portavocía del Gobierno. Madrid.

CANTER, L. W. (2007): Manual de evaluación de impacto ambiental. Técnicas para la elaboración de los estudios de impacto. Madrid, McGraw Hill. Cuarta edición, 841 pp.

CAÑADA TORRECILLA, R. et al., (2010): Situación actual y previsiones futuras de las disponibilidades hídricas de la Comunidad de Madrid y áreas circundantes. En Clima, ciudad y ecosistemas. AEC, nº 7 , Barcelona, pp. 349-366. 
CHARRAZA, A. (2011): Atlas climático ibérico. Ed. Ministerio de Medio Ambiente y Medio Rural y Marino, $79 \mathrm{pp}$.

SOTELO NAVALPOTRO, J. A. y ALCOLEA, M. A. (2005): Unidades fisiográficas, paisajes y espacios naturales protegidos en la región de Madrid. Madrid, revista de arte, geografía e historia, nº 7, pp. 337-372.

SOTELO NAVAlPOTRO, J. A. (2009): Las lógicas ilógicas del agua en los contextos de desarrollo. "Road to Copenhagen" Conference sustaining people and the Planet: a fair dial in Copenhagen.

SOTELO NAVALPOTRO, J. A. (2001): Estudiar la región. Madrid, INFODAL. pp. 285.

TORRES, T. et al., (2005): Génesis y edad del karst del Cerro de la Oliva y la Cueva del Reguerillo (Torrelaguna, Madrid). Libro homenaje al Profesor D. Rafael Fernández Rubio, pp. 225-242.

WESTMEN, W.E. (1985): Ecology, Impact Assessment, and Environmental Planning, Jon Wiley and Sons, New York, pp. 10-14. 